\title{
Dynamic Capabilities Associated with a Firm's Growth in Developing Countries. A Comparative Study of Argentinean SMEs in the Software and Tourism Industries
}

\section{Claudia D’Annunzio ${ }^{1}$, Mariela Carattoli, ${ }^{2}$ Dolores Dupleix ${ }^{3}$}

\begin{abstract}
Although recent evidence suggests that the development of dynamic capabilities (DC) is a key factor to gain and sustain competitive advantages to promote firm's growth, the question of how SMEs create, identify, and seize opportunities for growth have not been fully explored, particularly in developing countries with scarce resources. The aim of this study is to shed light on how SMEs develop capabilities to grow in the specific context of developing countries with resources constraints. To achieve a detailed description of the processes involved, this study applies a qualitative methodology based on a comparative case study of eight SMEs within the software and tourism industries in Argentine, which have been previously identified as dynamic sectors with high growth potential. Our findings suggest that SMEs develop DC mainly through an emerging process of iterative experimentation rather than through strategic planning. This process involves the coordination of organizational actions and resources, with managers playing a key role.
\end{abstract}

Keywords: firm's growth, dynamic capabilities, SMEs, developing countries.

\section{INTRODUCTION}

Recent evidence suggests that the development of dynamic capabilities (DC) is a key factor to gain and sustain competitive advantages to promote firm growth (Teece, Pisano \& Shuen, 1997; Teece, 2000, 2012; Helfat et al., 2007; Sapienza et al., 2006; Zollo \& Winter, 2002; Eisenhardt \& Martin,

1 Claudia D’Annunzio, Professor, MBA, National University of Central Buenos Aires, Centre for Studies in Management, Pinto 399, Tandil, Buenos Aires, Argentina; dannunzio@econ.unicen.edu.ar.

2 Mariela Carattoli, Ph.D. Student, MBA and M.Sc, National University of Central Buenos Aires, Centre for Studies in Management, Pinto 399, Tandil, Buenos Aires, Argentina; carattoli@econ.unicen.edu.ar

3 Dolores Dupleix, CONICET Fellowship, National University of Central Buenos Aires, Centre for Studies in Management, Pinto 399, Tandil, Buenos Aires, Argentina; dolores.dupleix@econ.unicen.edu.ar. 
2000). Additionally, many authors concluded that firms develop DC from an early stage (Zahra et.al, 2006) and that DC play a key role in the creation and evolution of startups (Sapienza et al., 2006). Since the introduction of this topic, intense debates have arisen in relation to the theoretical foundations of DC: the nature and the types of DC; the context in which DC are applied; and the relation between DC and competitive advantages (Carattoli, D'Annunzio \& Dupleix, 2014).

Particularly, earlier research on DC has primarily focused on large and established companies and has failed to address how SMEs develop DC to identify and seize opportunities to grow (Weiermair \& Peters, 2002; Peters \& Pikkemaat, 2006; Hall \&Williams, 2008; Hall, 2009; Hjalager, 2010). SMEs are important factors for economic and social development in both developed and developing countries (Charles, 2009). Successful SMEs generate employment, require less capital and management skills, and enable developing countries to participate in the global economy. Although some authors have addressed the topic of SMEs' performance and competiveness in developing countries, they focused on the impact of environmental factors rather than on the role of firm-level factors. As a consequence, there is little information on how competiveness of SMEs is created by factors other than the environment (Charles, 2009).

This paper provides empirical evidence on the development of DC in SMEs. The next sections present the theoretical framework of DC and a brief description of the context under analysis. Then, the methodological aspects are described followed by the empirical analysis.

Finally, we show the discussion section and conclusions.

\section{LITERATURE REVIEW}

\section{The concept of DC}

The framework of DC extends the resource-based view (RBV) examining the influences of dynamic environments (Helfat \& Peteraf, 2003). Specifically, Teece, Pisano, and Shuen (1997) proposed the concept of DC to describe how leading firms integrated, built, and reconfigured internal and external competencies to gain and maintain competitive advantages in rapidly changing environments. Since then, several researchers argue that dynamic capabilities are essential for increasing competitive advantages (Helfat \& Peteraf, 2009; Teece, 2007; Zahra et al., 2006; Zollo \& Winter, 2002; Zott, 2003) and for turning resources into improved performance (Wu, 2007).

As defined by Teece et al. $(1990,1997)$, DC are meta-processes that differ from ordinary capabilities, best practices, and competences in many aspects. 
These last concepts focus on the performance of a particular task and refer to "doing things right". Instead, DC refer to "doing the right things" (Teece, 2014). Specifically, DC focus on decisions about sensing opportunities, preparing the organization to seize opportunities, and creating adequate conditions to change and make adjustments in response to new environments.

Specifically, Teece (2007) proposed a DC framework and microfoundations of the capabilities required to sustain superior performance in open markets with high levels of innovation and resources globally allocated. In this regard, DC foster the firm to create, deploy, and protect the assets that support superior long-term performance. Firms with strong dynamic capabilities are intensely entrepreneurial: they not only adapt to dynamic business ecosystems, but also shape them through innovation and collaboration with other companies and institutions. This framework contributed to better understand the foundations of long-run success and help managers formulate strategic decisions. As a consequence, the DC framework explains firm competitiveness more effectively than the RBV (Teece et al., 1997; Eisenhardt \& Martin, 2000; Makadok, 2001; Zahra, Sapienza, \& Davidsson, 2006; Zollo \&Winter, 2002). Since Teece's research, many scholars have addressed different issues of DC. The majority of this research discusses DC in general terms and only a few studies are focused on defining where capabilities come from or what kinds of processes contribute to building them. However, some academics have recently addressed DC from new perspectives to improve the analysis and provide more empirical results.

With regard to the factors that influence DC, Sher and Lee (2004) studied both manufacturing and service firms and showed that internal and external knowledge management significantly affects DC; Prieto et al. (2009) concluded that autonomy and support are significant drivers of DC in firms focused on R\&D and innovation. Another empirical contribution was made by Liao, Kickul, and Ma (2009) who demonstrated that resource stock is positively related to the integrative capability in Internet-based firms. More recently, strategic orientations (Zhou \& Li, 2010) and network embeddedness (Zheng, Zhang, Wu \& Du, 2011) were identified as important drivers of DC in firms from a variety of manufacturing industries.

Many authors also identified that DC are directly related to the organizational learning culture (Hung, Yang, Lien, McLean \& Kuo, 2010) and embedded learning (Lee, Lin, Chen, \& Shyr, 2011). With regard to the tourism sector, Nieves and Haller (2014) recently investigated the possible antecedents of DC in the hotel industry and empirically showed that prior knowledge and skills at the individual and collective level are the basis for developing DC. They also concluded that firms with qualified employees are 
more likely to perceive the need for change and respond to it by reconfiguring the resource base.

Furthermore, many scholars have disaggregated the concept of DC. Ethiraj et al. (2005) found that client-specific capabilities and project management capabilities are fundamental for global firms in the software industry. Recently, Feiler \& Teece (2014) provided arguments on how DC are developed, and described ten DC demonstrating that they do not simply emerge or represent what firms do well. They are rather identified and built through the effort of leaders and managers to configure, orchestrate, and sustain activities to gain and maintain competitive advantage in rapidly changing and highly complex business environments.

To conclude, it is important to highlight that DC are context-specific and therefore, they should be conceptualized and empirically tested considering specific characteristics of each sector. Moreover, it is important to analyze the role of entrepreneurs and managers in the development of DC, considering their qualifications, prior experience, and managerial skills.

\section{DYNAMIC CAPABILITIES AND THE PHASES OF STRATEGY DEVELOPMENT}

\section{AND EXECUTION}

For analytical purposes, Teece (2007) suggested that dynamic capabilities may be disaggregated into three capacities: (1) to sense and shape opportunities and threats, (2) to seize opportunities, and (3) to maintain competitiveness through enhancing, combining, protecting, and reconfiguring assets (Teece, 2007). The author also describes the nature of dynamic capabilities, highlighting the microfoundations underlying the three DC. Microfoundations involve skills, processes, procedures, organizational structures, rules, etc.

\section{Capability to sense opportunities}

This capability involves activities such as scanning, creating, learning, and interpreting. Teece (2007: 1322) states that "when opportunities are first glimpsed, entrepreneurs and managers must figure out how to interpret new events, which technologies to pursue, and which market segments to target". To achieve that, firms need to generate information and make it flow along the entire organization to enable people to make sense of it. If firms do not engage in these activities, they fail may miss important market opportunities (Teece, 2007).

Besides, the ability to recognize opportunities depends on the individuals' capabilities and knowledge and on the organizational knowledge and learning skills, in general. Furthermore, the ability to get information from professional and social contacts and to understand that information 
are fundamental to deal with the evolution of technologies, to anticipate customer needs, and to face market changes in general. All these tasks involve scanning and monitoring internal and external factors; learning; interpretation, and creative activity from managers.

\section{Capability to seize opportunities}

Firm growth includes not only identifying technological and market opportunities but also seizing them: once opportunities are identified, they are supposed to turn into new products, processes or services. To achieve this, firms need to maintain and improve technological competences and resources and make necessary investment (Teece, 2007).

Consequently, in order to achieve superior performance, firms formulate an overall strategy to make decisions regarding critical issues, such as when, where, in what, and how much to invest. Besides, firms select or create a particular business model to define commercial and financial priorities (Teece, 2007). "Deciding how to capture value helps define the architecture and design of the business model" (Teece, 2007, p. 1330). In general, critical decisions are related to technological aspects, target market, funding, and other strategic issues.

Additionally, the design of a business strategy requires creativity, information, and skills to integrate know-how from the outside (from other organizations) and from inside the firm (Teece, 2007). Different perspectives from the outside may help firms to identify new opportunities and to create competitive advantages. On the contrary, firms may identify opportunities but are not able to seize them successfully.

\section{Capability to manage threats and orchestrate resources}

A key ability to gain long-term competitive advantages involves recombining and reconfiguring resources and organizational structures in order to face market and technological change. Teece claims that individuals are likely to create opportunities based on knowledge, creative activities, and the ability to understand customers 'needs. Thus, apart from their experience, mangers need to develop managerial skills to lead the firm efficiently.

Teece also highlights the importance of integrating external and internal know-how, which is likely to be achieved by networking activities. Furthermore, within each firm, "the old" and "the new" must be complemented. Finally, firms require effective communicational and informational mechanisms to keep managers permanently informed. 


\section{The role of DC in firm growth}

Firms' growth is a central concern in the strategic management literature. Most investigations have focused on the identification of internal and external factors that influence growth. Particularly, Entrepreneurship scholars have made significant efforts to explain how and why firms originate, develop, survive, and grow (Schumpeter, 1934; Penrose, 1959; Gartner, 1985; Davidsson, 2004; Zhara et. al., 2006; Dutta \& Thornhill, 2008; Stenholm \& Toivonen, 2009).

Although academics have adopted different explanatory approaches to address the question of why some firms perform better than others, many of them have offered evidence of the importance of DC for firms' growth. In fact, the literature is now unanimous in considering that the theoretical framework of DC explains how firms adjust their resources and activities to achieve and maintain sustainable competitive advantages (Ambrosini \& Bowman, 2009; Augier \& Teece, 2008; Cavusgil, Seggie, \& Talai, 2007). Competitive advantages are firms' attributes that allow them to outperform the competition. Thus, studying how firms compete and survive in the external environment is essential to understand the internal processes that take place within each firm.

Different theories explain the sources of competitive advantages. Most of this research has focused either on firms' opportunities and threats (Porter, 1980, 1985), firms' weaknesses and strengths (Hofer \& Schendel, 1978; Penrose, 1959; Stinchcombe, 1965). In particular, Teece proposes the theoretical framework of DC and claims these are high level capabilities that allow firms to recombine and reconfigure resources and organizational structures to remain flexible and face change (Teece et. al, 1997). Furthermore, DC help to avoid that critical organizational practices become excessively rigid. Thus, given that the present study focuses on SMEs in which foundersentrepreneurs play a central role in the development of DC, Teece provides a wide framework to identify which managerial skills are essential to engage in the evolving process of growth in SMEs.

\section{Context of the study}

In this paper we focus on analyzing the dynamic capabilities related to business growth in small and medium enterprises in a developing country such as Argentina. The cases were selected considering two of the most dynamic sectors in the national economy, and specifically in the economy of the central region of Buenos Aires provinces. These two sectors are software and IT services, and tourism. 
In Argentina, the Software and Information Services (SSI) has been expanding in both local and international markets, essentially based on entrepreneurial processes that exploit new technological opportunities, and the ability and creativity of their human resources. Indeed, human resources are the country's main competitive advantage in comparison with other economies. Recently, the Argentinean SSI industry has shown a significant growth according to international standard indicators, such as sales growth, employment and exports.

According to the annual report of the Chamber of Enterprises in the Software and Computer Services of Argentina (CESSI), between 2003 and 2013 the number of companies in this industry increased by $132 \%$. In 2014, there were 4300 registered firms, of which $70 \%$ were small firms with up to fifty employees (CESSI, 2015). Moreover, with an annual birth rate of $20 \%$, the SSI sector in Argentine has become the second most dynamic economic sector since 2003.

The main feature of this industry is the potential to add value and generate qualified employment. In particular, there is a continuous increase in the export of services, and there is a great demand for qualified human resources. This sector employs over 51,000 people and $50 \%$ of these jobs are concentrated in SMEs with less than 25 employees. The Argentinean SSI industry offers a wide range of products such as customized software; consulting; support services; implementation of applications; development of computer solutions; and products for business management and security tools. Recently, the development of the SSI industry has become a national strategic priority.

Furthermore, the growing economic importance of the SSI sector has led to the development of clusters. Although this sector is highly concentrated in Buenos Aires City, many other significant concentrations of technological and managerial capabilities are located in several cities of the country such as Rosario, Cordoba, Mendoza and Bariloche. At the same time, other smaller cities have been involved in different initiatives to develop the SSI sector. For example, Tandil, a city located in the center of Buenos Aires Province. In 2003, a Technological Center was established with a strong support from the local University (UNICEN), from where most of the computing engineers emerge. Thus, the city has become a very important provider of SSI services in the national industry.

Currently, Tandil hosts more than $100 \mathrm{SSI}$ companies which have created more than 1500 jobs since its initiation. Previous studies (D'Annunzio et al., 2008) concluded that the local SSI sector operates in a very dynamic and competitive market. SSI firms face continuous changes both in technology and in the international market demands. Besides, this sector is largely composed 
by startups or relatively young firms that operate locally and incorporate young people, mainly university graduates. Although there are some large firms, the SSI sector is mainly composed of small and medium enterprises.

In Argentina, the tourism sector has experience a strong growing tendency in terms of the flow of tourists and the level of employment. Thus, according to the National Ministry of Tourism, the arrival of nonresident tourists to Argentina grew between 2003 and 2013 from 2,995,272 to $7,543,975$, representing a growth of about $86 \%$ of the touristic flow. Furthermore, in that same period accommodation rose by $40.5 \%$ and employment levels experienced an increase of about $25.2 \%$ from 882,125 in 2004 to $1,104,439$ in 2013. According to the Argentinean Confederation of Medium-sized enterprises, the tourism activity accounts for about $8 \%$ of the GDP in Argentina. Besides, the tourism sector generates about 7, 3\% of the total employment in the country. Considering all the participants within the tourism activity, SMEs are preponderant: currently, there are more than 200.000 companies operating in the tourism sector, $95 \%$ of which are micro, small, and medium-sized enterprises (CAME, 2013).

Thus, many cities around the country have developed a wide range of touristic activities and for many regional economies tourism is the main source of income. Tandil is a good example of that. Tandil is certainly recognized as one of the main touristic destinations in Buenos Aires Province and in the whole country as well. The tourism sector has experienced a sustained upward trend in terms of the flow of tourists and employment levels as well. Furthermore, Tandil is geographically located in the middle of the Province and its landscape is appropriate to develop the tourist activity. Indeed, the hills and natural environment made Tandil an incomparable place in Argentina. This city has capacity to host about 5660 visitors, $25 \%$ of which is provided by cottage resorts, as the ones considered in this study, according the classification proposed by the local government (hotels and cottage resorts have different treatments).

\section{RESEARCH METHODS}

Most studies on DC are conceptual and there is little empirical research on DC in SMEs. The main reason for this is the difficulty of operationalizing the concept of DC (Ambrosini \& Bowman, 2009; Teece, 2012). Thus, it is important to increase the number of empirical studies on DC and to apply qualitative methodologies in order to provide detailed descriptions of all the processes involved in the development of DC (Danneels, 2011; Teece, 2012).

In the present study we analyze different business cases in order to better understand the origins of DC. Particularly, we apply an exploratory 
strategy orientated towards the identification of the factors that influence the development of DC, the difficulties encountered in the process, and the role of entrepreneurs in the firms' performances. Based on this, the research was designed according to the multiple cases methodology, which was originally proposed by Yin (1989), and according to the process of inducing theory described by Eisenhardt (1989). This methodology is useful to obtain a detailed evaluation of each case individually (Bryman \& Bell, 2007) and to better understand a phenomenon within its specific setting (Saunders et al, 2009). Additionally, Backman (1998) highlights that qualitative research strategies focus on individuals and how they interpret their reality based on their background. In this case, this is important to understand the whole process of DC and provide a convincing interpretation of facts.

This analysis includes eight firms from Tandil, a centrally located city in Buenos Aires Province (Argentine). In order to provide significant results (Patton, 1990) all the cases were selected from representative sectors in the regional economy: four cases from the software industry and four from the tourism sector. To select the cases, we considered certain criteria. Firms should be located in Tandil, Buenos Aires, a city that hosts one of the most important IT Centers in the country (Argentine) and it is a popular destination for tourists from around the country throughout the year. Besides, firms should be classified as young SMEs, according to the age and the number of employees and/or turnover. Lastly, firms should have been operating for at least three years, so that the development of dynamic capabilities could be studied as a process over time.

Based on these criteria and considering information from the researchers and from various entrepreneurial networks located in the city, eight companies were selected. Then, we contacted the owners of the firms to start the research process. Data was obtained through qualitative research techniques, including direct observation conducted by two members of the research group, and personal in-depth interviews conducted between August, 2013 and April, 2014. We also gathered information from different websites.

As Saunders et al. suggest, in exploratory research it is important to interview key informants (Saunders et al., 2009). In this case, we decided to contact the founders or the general managers of each firm. Depending on the firm, we interviewed the only founder or one or more of the founding team. All the interviews were held in the respondents' natural setting. Because of the exploratory purpose of this study, the perspectives and the interpretations provided in the stories told by the entrepreneurs were the main source of information. 
To collect all the necessary information and to address every important aspect of DC, a guiding list of key questions and specific issues was prepared according to the theoretical framework. At the same time, we fostered interviewees to express openly to make the conversations more interesting and dynamic. The questions were mainly orientated towards defining the concept DC in SMEs; identifying the main DC to compete and position in the market; describing the main internal and external factors influencing the evolution of the firms; and determining the main managerial processes involved in the development of DC. Furthermore, to perform a detailed analysis, we asked each interviewee whether the conversations could be recorded or not.

At the beginning of each interview we asked the respondents to describe the main strategic actions taken in relation to the identification and assessment of business opportunities. This question encouraged the entrepreneurs to lead the conversation and tell their story in as much detail as possible. However, we involved in the conversation to ask additional questions and remind the respondents about the importance to fully address concepts, actions and interpretations. Due to this flexibility, we were able to organize and adapt questions if needed (Jovchelovitch \& Bauer, 2000; Andersen, 2002).

Backman (1998) argues that one of the most difficult steps in qualitative research is the analysis of data. This is because case studies involve a big amount of subjectivity and opinion, and the vast majority of the results derive from personal interpretations rather than from statistical models such as in quantitative research.

In order to perform a careful analysis, all the interviews were recorded for later transcription. Then, all that information was integrated in a single document. The analysis involved an iterative process of interpreting and encoding data based on the researchers' individual perspectives and the theoretical framework applied in the study (Creswell, 2007); comparing interpretations; and discussing categorical concepts.

First, all the transcripts were analyzed separately in order to identify and classify the emerging categories in relation to the following aspects: Customers and Markets, Product and Services; Business Model; Key Resources, and Capabilities and Main Focus. For each of these items we then identified significant events or changes and determined "phases" or different stages in relation to the growth path of each company. This analysis is briefly presented in Tables 1 to 8.

Second, we conducted a comparative analysis across cases, based on Teece's framework of DC and its microfoundations. To organize results we assigned qualitative values to identify the differences between the cases in 
relation to the growth path and the DC appropriately developed. To assess growth we considered two categories: gradual and accelerated growth, depending on the speed with which the company has been adding new staff over time. To assess the intensity of each DC, we applied a qualitative scale ranging from VERY WEAK to VERY STRONG. Additionally, we identified the key factors involved in the development of DC. Based on this analysis, we were able to compare and contrast the same phenomenon between the different cases and reach more precise conclusions in relation to both economic sectors. Tables 9 and 10 show the analysis described above.

\section{Empirical analysis}

In this section, we present a brief analysis of each case. First, we describe the firm and then show a table summarizing the firms' growth path. The table shows results with regard to customers and markets, products and services; business models; resources; capabilities, and main focus and it is divided into phases, according to significant events or changes that were identified as key factors in the evolution of the firms.

\section{Firm A}

$A$ is a software consulting and development company that was founded in 2006 by two young Systems Engineers. Their company designs, implements and optimizes technological solutions and applications, and specializes in offshore software development, product testing and design, and database management. The main customers are located in the United States, Chile, Spain, Brazil, and Germany, and the minority is from Argentina. The firm started providing services with only two employees and now it has a staff of thirty people, including systems engineers and software designers. Table 1 summarizes the main aspects that explain the evolution of $A$, identifying specific capabilities associated to the growth of the firm.

In this case it was possible to identify four distinct stages in the company's growth path. Each stage is associated with milestones in the commercial expansion. The first stage included the beginning of the company, which was completely dependent on a single client from Chile.

In the second stage FIRM A attracted new customers, though through business intermediaries. By that moment, the Chilean customer had merged and started pushing FIRM A to become their exclusive development. However, an important US client encouraged FIRM $A$ to remain an independent company. 
Table 1. Capabilities related to the growth of Firm A

\begin{tabular}{|c|c|c|c|c|}
\hline & $\begin{array}{l}\text { Phase I: } \\
2006 \text { - } 2007\end{array}$ & $\begin{array}{l}\text { Phase II: } \\
2007 \text { - } 2009\end{array}$ & $\begin{array}{l}\text { Phase III: } \\
\text { 2009-2011 }\end{array}$ & $\begin{array}{l}\text { Phase IV: } \\
2011 \text { - present }\end{array}$ \\
\hline $\begin{array}{l}\text { TO WHOM? } \\
\text { Customers and } \\
\text { Markets } \\
\text { How customers } \\
\text { and the target } \\
\text { market have } \\
\text { changed over } \\
\text { time? }\end{array}$ & $\begin{array}{l}\text { One single } \\
\text { customer from } \\
\text { Chile }\end{array}$ & $\begin{array}{l}\text { Customers } \\
\text { from the US } \\
\text { and Germany } \\
\text { contacted } \\
\text { through } \\
\text { entrepreneurs } \\
\text { 'networking } \\
\text { activities }\end{array}$ & $\begin{array}{l}\text { First client } \\
\text { contacted } \\
\text { through direct } \\
\text { commercial } \\
\text { relations with } \\
\text { the company in } \\
\text { Germany }\end{array}$ & $\begin{array}{l}\text { Positioning in } \\
\text { the market of US } \\
\text { startups. } \\
\text { Beginning of the } \\
\text { process of inter- } \\
\text { nationalization of } \\
\text { the company }\end{array}$ \\
\hline $\begin{array}{l}\text { WHAT? } \\
\text { Products and } \\
\text { services } \\
\text { How has the } \\
\text { supply changed } \\
\text { over time? }\end{array}$ & $\begin{array}{l}\text { Software } \\
\text { development and } \\
\text { maintenance for } \\
\text { a single client }\end{array}$ & $\begin{array}{l}\text { Software } \\
\text { development } \\
\text { for an enlarged } \\
\text { customer base } \\
\text { in different } \\
\text { countries }\end{array}$ & $\begin{array}{l}\text { Software } \\
\text { development } \\
\text { for an enlarged } \\
\text { customer base } \\
\text { in different } \\
\text { countries }\end{array}$ & $\begin{array}{l}\text { Text search } \\
\text { technologies for } \\
\text { Oracle. } \\
\text { Database } \\
\text { Management and } \\
\text { Testing. } \\
\text { Software } \\
\text { for mobile } \\
\text { applications }\end{array}$ \\
\hline $\begin{array}{l}\text { HOW? } \\
\text { Business model } \\
\text { How has the } \\
\text { business model } \\
\text { changed over } \\
\text { time? }\end{array}$ & $\begin{array}{l}\text { The business } \\
\text { was focused on } \\
\text { programming }\end{array}$ & $\begin{array}{l}\text { Software } \\
\text { development } \\
\text { Diversified target } \\
\text { markets }\end{array}$ & $\begin{array}{l}\text { Software } \\
\text { development } \\
\text { Diversified target } \\
\text { markets }\end{array}$ & $\begin{array}{l}\text { Specialization } \\
\text { in specific } \\
\text { technologies } \\
\text { Positioning in the } \\
\text { main worldwide } \\
\text { startups market } \\
\text { (USA) }\end{array}$ \\
\hline $\begin{array}{l}\text { WITH WHAT? } \\
\text { Key resources } \\
\text { and capabilities } \\
\text { What have been } \\
\text { the key resources } \\
\text { and capabilities } \\
\text { at each stage? }\end{array}$ & $\begin{array}{l}\text { Technical training } \\
\text { and experience of } \\
\text { entrepreneurs in } \\
\text { large established } \\
\text { technology } \\
\text { companies }\end{array}$ & $\begin{array}{l}\text { Entrepreneurs } \\
\text { 'networks with } \\
\text { personal and } \\
\text { professional } \\
\text { contacts Ability } \\
\text { to seize identified } \\
\text { opportunities }\end{array}$ & $\begin{array}{l}\text { Creativity } \\
\text { in business } \\
\text { management to } \\
\text { attract customers } \\
\text { and training of } \\
\text { entrepreneurs } \\
\text { in business } \\
\text { management } \\
\text { (MBA) }\end{array}$ & $\begin{array}{l}\text { Access to venture } \\
\text { capital to foster } \\
\text { growth. } \\
\text { Business } \\
\text { orientation. } \\
\text { Development } \\
\text { of innovative } \\
\text { products. } \\
\text { Ability to } \\
\text { reconfigure the } \\
\text { business model. }\end{array}$ \\
\hline $\begin{array}{l}\text { FOCUS } \\
\text { What was the } \\
\text { main concern in } \\
\text { each phase? }\end{array}$ & $\begin{array}{l}\text { Identification } \\
\text { of business } \\
\text { opportunities } \\
\text { other than the } \\
\text { Chilean client } \\
\text { to enable both } \\
\text { independence } \\
\text { and survival of } \\
\text { the company }\end{array}$ & $\begin{array}{l}\text { Development } \\
\text { of competitive } \\
\text { advantages based } \\
\text { on high quality } \\
\text { standards of } \\
\text { services to face } \\
\text { the difficulty in } \\
\text { maintaining cost } \\
\text { advantages after } \\
\text { the exchange rate } \\
\text { devaluation }\end{array}$ & $\begin{array}{l}\text { Effective } \\
\text { and efficient } \\
\text { management of } \\
\text { ongoing projects } \\
\text { and the attraction } \\
\text { and retention of } \\
\text { talent }\end{array}$ & $\begin{array}{l}\text { Business model } \\
\text { reconfiguration } \\
\text { orientated } \\
\text { towards the } \\
\text { specialization } \\
\text { in specific } \\
\text { technologies. } \\
\text { Access to the } \\
\text { American } \\
\text { software market. }\end{array}$ \\
\hline
\end{tabular}


The third step in the growth process was taken when the entrepreneurs attracted their first customer through their own commercial strategies. This is important because the interviewees repeatedly emphasized how challenging it was to manage commercial relationships.

Since 2011, the entrepreneurs have defined new challenges and the firm entered a new phase, which aims at the specialization in no-massive technologies that require longer learning processes, and to the expansion towards a key target market: US. To this end, the entrepreneurs have decided to seek for short-term investors and to temporally settle in the US for networking. Thus, the company has been working on developing products for free text search; providing database management; testing services; and developing mobile technology. Particularly, the firm has focused on large volumes of information in real time (Big Data).

All these strategic changes also implied changes in the structure and management of the projects. At the beginning, the entrepreneurs had a complete lack of business experience and limited resources and their growth expectations were not ambitious. As they started working and gaining experience, particularly on business management, they increased their ambitions to grow. At the same time, their problems and drawbacks have also changed from one stage to the other. Initially, although it was relatively easy to find qualified human resources in the local market, entrepreneurs were concerned about finding customers and entering new markets. Under these circumstances, the entrepreneurs felt a low risk perception. However, after many changes in the firm's and market's conditions, they increased the risk perception and focus on two specific issues: project management and human resource management.

During the last years the firm has identified a key problem to grow: the difficulty in finding qualified and committed human resources. Furthermore, a common problem that most IT firms face is that they involve in temporary projects but they need to hire permanent human resources and retain them. Thus, skills for human resource management are a key factor of success in this kind of companies.

\section{Firm B}

B Argentina began operating in 2004 as a Research and Development Center of Internet Solutions for a Spanish technology group in the ICT sector. This group was founded in 1995 and currently it has a staff of more than 240 people working in Girona, Barcelona, Madrid, Buenos Aires, and Silicon Valley. The Spanish group consists of different companies that provide email security solutions, online business consulting, information technologies, 
software development, and incubation of innovative technology solutions. $B$ Argentina started providing services with two employees in 2004 . Then, in 2010 the firm consisted of almost seventy employees and currently it has thirty-eight employees.

Table 2. Capabilities related to the growth of Firm B

\begin{tabular}{|c|c|c|c|}
\hline & $\begin{array}{l}\text { Phase I: } \\
\text { 2004- 2007 }\end{array}$ & $\begin{array}{l}\text { Phase II: } \\
\text { 2007-2011 }\end{array}$ & $\begin{array}{l}\text { Phase III: } \\
2011 \text { - present }\end{array}$ \\
\hline $\begin{array}{l}\text { TO WHOM? } \\
\text { Customers and Mar- } \\
\text { kets } \\
\text { How customers and } \\
\text { the target market } \\
\text { have changed over } \\
\text { time? }\end{array}$ & $\begin{array}{l}\text { Developments made } \\
\text { exclusively for the } \\
\text { Spanish headquarter. }\end{array}$ & $\begin{array}{l}\text { Marketing of softwa- } \\
\text { re developments to } \\
\text { other companies be- } \\
\text { longing to the Spa- } \\
\text { nish group. }\end{array}$ & $\begin{array}{l}\text { Developments are } \\
\text { extended to companies } \\
\text { belonging to the Spa- } \\
\text { nish group and also to } \\
\text { spin off arising from bu- } \\
\text { siness incubation within } \\
\text { the group. }\end{array}$ \\
\hline $\begin{array}{l}\text { WHAT? } \\
\text { Products and services } \\
\text { How has the supply } \\
\text { changed over time? }\end{array}$ & $\begin{array}{l}\text { Provision of Consul- } \\
\text { ting Services and So- } \\
\text { ftware Maintenance }\end{array}$ & $\begin{array}{l}\text { Software Consulting } \\
\text { and Development of } \\
\text { innovative products. }\end{array}$ & $\begin{array}{l}\text { Software Consulting. } \\
\text { Innovative product de- } \\
\text { velopment and incuba- } \\
\text { tion of projects and ge- } \\
\text { neration of new startups }\end{array}$ \\
\hline $\begin{array}{l}\text { HOW? } \\
\text { Business model } \\
\text { How has the business } \\
\text { model changed over } \\
\text { time? }\end{array}$ & $\begin{array}{l}\text { Software Develop- } \\
\text { ment Center for the } \\
\text { Spanish headquarter }\end{array}$ & $\begin{array}{l}\text { Software Develop- } \\
\text { ment Center for } \\
\text { companies associa- } \\
\text { ted with the Spanish } \\
\text { group }\end{array}$ & $\begin{array}{l}\text { Software Development } \\
\text { Center for the Spanish } \\
\text { headquarters and other } \\
\text { companies associated to } \\
\text { the group. } \\
\text { Incubation of projects } \\
\text { and generation of new } \\
\text { startups }\end{array}$ \\
\hline $\begin{array}{l}\text { WITH WHAT? } \\
\text { Key resources and ca- } \\
\text { pabilities } \\
\text { What have been the } \\
\text { key resources and ca- } \\
\text { pabilities at each sta- } \\
\text { ge? }\end{array}$ & $\begin{array}{l}\text { Technical training and } \\
\text { entrepreneurs' expe- } \\
\text { rience. } \\
\text { Networking with in- } \\
\text { ternational contacts. } \\
\text { Exploitation of op- } \\
\text { portunities. }\end{array}$ & $\begin{array}{l}\text { Ability to innova- } \\
\text { te and develop new } \\
\text { products. } \\
\text { Linkages and co-wor- } \\
\text { king with research } \\
\text { centers at the uni- } \\
\text { versity. }\end{array}$ & $\begin{array}{l}\text { Know-how in project } \\
\text { management, develop- } \\
\text { ment of startups, and } \\
\text { product innovations. }\end{array}$ \\
\hline $\begin{array}{l}\text { FOCUS } \\
\text { What was the main } \\
\text { concern in each pha- } \\
\text { se? }\end{array}$ & $\begin{array}{l}\text { To reach a high quali- } \\
\text { ty standard of servi- } \\
\text { ces and processes }\end{array}$ & $\begin{array}{l}\text { Consolidation of } \\
\text { working teams with } \\
\text { experience in develo- } \\
\text { ping products for the } \\
\text { international market }\end{array}$ & $\begin{array}{l}\text { Firm growth in a market } \\
\text { where the firm is less } \\
\text { competitive than it was } \\
\text { at the beginning. }\end{array}$ \\
\hline
\end{tabular}

The growth of firm B has always depended on the evolution and growth of the Spanish group to which it belongs. It is also influenced by the creation of new businesses within the group, and the generation of international networks through the companies' CEOs' mobility. The firm's business model limited its opportunity to formulate its own strategy and grow individually. All this had a significant impact on B's possibility to develop and enhance essential 
capabilities. As a consequence, the main weakness the entrepreneurs have showed is the difficulty in attracting their own customers.

Considering these conditions, three stages were identified in the growth path of the company. During the first stage all the software developments were made for the Spanish headquarter exclusively. In the second stage, the expansion of the parent company resulted in the expansion of B's development activities for other business units within the group. The third stage of B's evolution is related to the provision of services to many of the company's spinoffs.

At the beginning, the entrepreneurs were concerned about the quality of their products and processes. Thus, they invested and worked heavily in training to be able to certificate quality according to the standards of the ISO 9001 (International Organization for Standardization). Later, their main concern was the change in the business model: the firm started working for small projects requested by the parent company and then became a business incubator. Additionally, during the process, B gained a key competitive advantage: the know-how of developing and managing projects for startups, adding value not only in the development stage but also in the generation of product innovations.

\section{Firm C}

$C$ is a company that develops agile software located in the United States and South America. The firm was founded in 2006 by two entrepreneurs and later another partner joined to the founding team. $C$ develops near shore software and has a wide customer base. The firm provides high performance agile products that provide and customer services. The main supply of $C$ includes consulting technology, Entertainment Digital Media, Cloud Computing, Java and Net, Software Architecture, Agile Software Development, Amazon Web Services and Project Management, among others.

The firm started operating with a group of 11 people and currently they are about 80 people and continuing to expand. Their most recent wave of growth is onshore in the United States and they are bringing up development teams and managers to work onsite with their clients, acting as a bridge to their delivery centers in South America.

C's path growth is divided into three stages depending on the business models developed along its evolution (Table 3). The company started operating at the middle of 2006 when the entrepreneurs identified that the media industry was changing towards digitization and automation. They decided to create a tool to process multimedia content and digital information automatically. The product was mainly offered to major television and cinema 
studios. Initially, the business was self-financed with resources from "the three Fs" (family, friends and fools) but then the entrepreneurs gained access to a venture round of 1 million dollars. In that occasion, they had the opportunity to present the product to be evaluated by the owners of important business such as Disney, New Brothers, American Idol, Fox, and Sony.

Table 3. Capabilities related to the growth of Firm C

\begin{tabular}{|c|c|c|c|}
\hline & $\begin{array}{l}\text { Phase 1: } \\
2006-2011\end{array}$ & $\begin{array}{l}\text { Phase II: } \\
\text { 2011-2012 }\end{array}$ & $\begin{array}{l}\text { Phase III: } \\
\text { 2012- present }\end{array}$ \\
\hline $\begin{array}{l}\text { TO WHOM? } \\
\text { Customers and Mar- } \\
\text { kets } \\
\text { How customers and } \\
\text { the target market } \\
\text { have changed over } \\
\text { time? }\end{array}$ & $\begin{array}{l}\text { Major companies in } \\
\text { the movie and televi- } \\
\text { sion industries, such } \\
\text { as Sony and Disney }\end{array}$ & $\begin{array}{l}\text { Large established } \\
\text { firms in the interna- } \\
\text { tional market. }\end{array}$ & $\begin{array}{l}\text { Large established } \\
\text { firms in the interna- } \\
\text { tional market } \\
\text { (Accenture, Coca } \\
\text { Cola, All digital, Delu- } \\
\text { xe, Discovery Commu- } \\
\text { nications) }\end{array}$ \\
\hline $\begin{array}{l}\text { WHAT? } \\
\text { Products and services } \\
\text { How has the supply } \\
\text { changed over time? }\end{array}$ & $\begin{array}{l}\text { Digital tool for auto- } \\
\text { matic processing of di- } \\
\text { gital information }\end{array}$ & $\begin{array}{l}\text { Cloud computing } \\
\text { technologies }\end{array}$ & $\begin{array}{l}\text { Technology consulting } \\
\text { of Digital Media and } \\
\text { Entertainment, Clo- } \\
\text { ud Computing, Java } \\
\text { and .Net, Software Ar- } \\
\text { chitecture, Agile So- } \\
\text { ftware Development, } \\
\text { Amazon Web Servi- } \\
\text { ces and Project Mana- } \\
\text { gement. }\end{array}$ \\
\hline $\begin{array}{l}\text { HOW? } \\
\text { Business model } \\
\text { How has the business } \\
\text { model changed over } \\
\text { time? }\end{array}$ & $\begin{array}{l}\text { Postproduction distri- } \\
\text { bution to movie stu- } \\
\text { dios, television broad- } \\
\text { casts, and advertising } \\
\text { agencies }\end{array}$ & $\begin{array}{l}\text { Supply of integrated } \\
\text { technology services }\end{array}$ & $\begin{array}{l}\text { Software develop- } \\
\text { ment near shore and } \\
\text { specialization in high } \\
\text { quality services. }\end{array}$ \\
\hline $\begin{array}{l}\text { WITH WHAT? } \\
\text { Key resources and ca- } \\
\text { pabilities } \\
\text { What have been the } \\
\text { key resources and ca- } \\
\text { pabilities at each sta- } \\
\text { ge? }\end{array}$ & $\begin{array}{l}\text { Entrepreneurs 'techni- } \\
\text { cal training and expe- } \\
\text { rience. } \\
\text { Networking }\end{array}$ & $\begin{array}{l}\text { Active learning gene- } \\
\text { rated from previous } \\
\text { experience operating } \\
\text { in the US market. } \\
\text { Ability to reconfigure } \\
\text { the business model. }\end{array}$ & $\begin{array}{l}\text { Sound knowledge of } \\
\text { the market ecosystem } \\
\text { where the service is } \\
\text { provided. } \\
\text { Organizational culture } \\
\text { International Ne- } \\
\text { tworks }\end{array}$ \\
\hline $\begin{array}{l}\text { FOCUS } \\
\text { What was the main } \\
\text { concern in each pha- } \\
\text { se? }\end{array}$ & $\begin{array}{l}\text { The media industry } \\
\text { was moving towards } \\
\text { digitization and auto- } \\
\text { mation. } \\
\text { To find a product that } \\
\text { will generate attrac- } \\
\text { tion to large custo- } \\
\text { mers }\end{array}$ & $\begin{array}{l}\text { Strengthen sales rates } \\
\text { Redefine business }\end{array}$ & $\begin{array}{l}\text { Growing shortage of } \\
\text { qualified staff. The } \\
\text { company gets invo- } \\
\text { Ived in this situation } \\
\text { and decide to tra- } \\
\text { in human resources } \\
\text { in-company }\end{array}$ \\
\hline
\end{tabular}


However the evolution of the business was slower than expected and the entrepreneurs were not able to make it a profitable organization. Thus, they took a new step and sold the intellectual property to a US company. Then, the firm redefined the business model and started providing services for large established firms in the international market. During the first stage of this project, they focus on learning and formulating a viable strategy. Then, they took another step and expanded their services and consequently their capabilities. Currently, the firm is running a new business model based on a wide range of high quality services for large established firms in the international market such as Accenture, Coca Cola, All digital, Deluxe, Discovery Communications.

\section{Firm D}

$D$ provides services for people who decide to get rid of things they do not longer want or use at their homes or workplaces and are determined to sell them. The firm's services include all the activities related to the different stages in the sales process. Users should only send a message describing the product. After that, $D$ is in charge of picking the product to then advertise it online. Once the sale is agreed, $D$ is in charge of the products ' packaging and distribution. Currently, this service is operating in San Francisco (California) and Austin (Texas). $D$ works with leading investors within the industry, such as Techstars Ventures, MasterCard, Silicon Valley Bank, Cygnus Capital, NXTP Labs, Grooveshark's cofounder, Andres Barreto, and Uber's CTO and cofounder, Oscar Salazar.

At the beginning there were only two founder entrepreneurs and currently they are a group of sixteen people.

This startup was born in Austin, while the founder entrepreneurs were participating in a startup accelerator and development program at Techstars to present a project called Productgram, which was successfully accepted (Table 4). Then, the entrepreneurs spent a month analyzing the US market, along with professional advisors and mentors, and identified a surprising fact: each home kept about three thousand dollars in unused objects. They also found that those objects were not posted at traditional marketplaces such as eBay or Craigslist because of all the problems that consumers faced when trying to sell them. Selling those products not only includes listing the products online, but other activities such as pricing, packing, labeling, sending the package through UPS or Fedex, and charging. 
Table 4. Capabilities related to the growth of Firm D

Phase I: 2012-2014

TO WHOM?

Customers and Markets

Contacts from Austin, US, generated through social

How customers and the target networks and social circles market have changed over

time?

WHAT?

Products and services

How has the supply changed over time?

HOW?

Business model

How has the business model changed over time?

WITH WHAT?

Key resources and capabilities What have been the key resources and capabilities at each stage?

FOCUS

What was the main concern in each phase?
Application to sell different products through social networks and e-commerce platforms. ("Instagram for products").

Marketplace model: the company is responsible for marketing activities.

Entrepreneurial team Participation in Business Accelerator programs: NXTP Labs and Techstars. Funding from a mutual fund, Signus VC, and from Andrés Barreto, Grooveshark's founder.

Develop, refine and test the business idea.

Attract funding
Phase II: 2014-present

Public in general.

Consumers from Austin and

San Francisco, US.

App to sell useless devices and objects

Value maximization

Dealing with all the stages

along the sales process.

Service layer model Focus on critical logistics issues.

Enlarged working the team and development of partnerships with American companies that have innovative logistics capabilities.

Active business development activities

Adequate fit between the products 'supply and demand to grow in the American market.

Based on this opportunity, the entrepreneurs decided to refocus their business idea and created D in 2012. D is a service layer above traditional marketplaces that provides all the mentioned services. The new project involved intense logistics activities that led the founding team to expand and develop partnerships with logistic leading American companies. The new venture also involved the development of new skills and managerial activities.

Due to the short age of this firm only two stages were identified. The first period is related to the beginning of the project. Then, they took an important step and expanded their services to new locations. In this second stage the entrepreneurs enlarged the working team and develop critical skills in logistics management. 


\section{Firm $\mathrm{E}$}

$E$ is a cottage resort that provides adventure activities and nature sports. The firm has been operating for 25 years (Table 5). At the beginning, the entrepreneurs were the only people in charge of all the entrepreneurial and operational tasks and activities. Currently $E$ has a staff of 40 people. The company also offers educational camp services, outdoor training, and outdoor experiential training. The majority of the customers are from private schools and companies, NGOs, and other public and private organizations. Most of the clients are from Buenos Aires city. During the first stages, $E$ faced a strong seasonality in sales, exclusively concentrated in the period between September and December. Nowadays, the firm has achieved a more steady demand, providing different services throughout the year.

Table 5. Capabilities related to the growth of Firm E

\begin{tabular}{|c|c|c|c|}
\hline & $\begin{array}{l}\text { Phase I: } \\
\text { 1989-1993 }\end{array}$ & $\begin{array}{l}\text { Phase II: } \\
\text { 1993-2002 }\end{array}$ & $\begin{array}{l}\text { Phase III: } \\
\text { 2002-present }\end{array}$ \\
\hline $\begin{array}{l}\text { TO WHOM? } \\
\text { Customers and } \\
\text { Markets } \\
\text { How customers and } \\
\text { the target market have } \\
\text { changed over time? }\end{array}$ & $\begin{array}{l}\text { Local organizations } \\
\text { Sporadic and seasonal } \\
\text { demand }\end{array}$ & $\begin{array}{l}\text { Private schools } \\
\text { from Buenos } \\
\text { Aires } \\
\text { Seasonal demand }\end{array}$ & $\begin{array}{l}\text { Schools, organizations, } \\
\text { and companies } \\
\text { Demand throughout the } \\
\text { year }\end{array}$ \\
\hline $\begin{array}{l}\text { WHAT? } \\
\text { Products and services } \\
\text { How has the supply } \\
\text { changed over time? }\end{array}$ & Tours and excursions & $\begin{array}{l}\text { Educational } \\
\text { Camp services }\end{array}$ & $\begin{array}{l}\text { Educational Camp } \\
\text { services, outdoor training } \\
\text { and summer camps }\end{array}$ \\
\hline $\begin{array}{l}\text { HOW? } \\
\text { Business model } \\
\text { How has the business } \\
\text { model changed over } \\
\text { time? }\end{array}$ & $\begin{array}{l}\text { Independent services. } \\
\text { Not based on } \\
\text { horizontal or vertical } \\
\text { integration. } \\
\text { Own design and plan } \\
\text { of the firm's value } \\
\text { chain. }\end{array}$ & Customer loyalty & $\begin{array}{l}\text { Business model based on } \\
\text { technical and commercial } \\
\text { synergies. } \\
\text { Development of new } \\
\text { business units }\end{array}$ \\
\hline $\begin{array}{l}\text { WITH WHAT? } \\
\text { Key resources and ca- } \\
\text { pabilities } \\
\text { What have been the } \\
\text { key resources and ca- } \\
\text { pabilities at each stage? }\end{array}$ & $\begin{array}{l}\text { Natural context } \\
\text { and favorable } \\
\text { environment to } \\
\text { develop the activities }\end{array}$ & $\begin{array}{l}\text { Commercial } \\
\text { and marketing } \\
\text { management. } \\
\text { Infrastructure } \\
\text { development }\end{array}$ & $\begin{array}{l}\text { Strategic management } \\
\text { New products and } \\
\text { services development }\end{array}$ \\
\hline $\begin{array}{l}\text { FOCUS } \\
\text { What was the main } \\
\text { concern in each } \\
\text { phase? }\end{array}$ & $\begin{array}{l}\text { Design attractive } \\
\text { products } \\
\text { Attract new customers }\end{array}$ & $\begin{array}{l}\text { Reach a more } \\
\text { steady demand } \\
\text { Reduce fixed } \\
\text { costs. }\end{array}$ & $\begin{array}{l}\text { Business } \\
\text { professionalization HR } \\
\text { management } \\
\text { Training for future firm } \\
\text { members from the own } \\
\text { family }\end{array}$ \\
\hline
\end{tabular}


The key features of E's evolution are the high level of investment in infrastructure and the emphasis on building capabilities related to innovation in services and processes. During the first stage, the firm provided daily excursion services to different target customers. The services included food and lodging.

As their services attracted new clients, the entrepreneurs decided to invest in infrastructure (dining, accommodation, etc.) and took a step forward. They also designed a new business strategy based on close relationships with customers and high-quality services. The entrepreneurs focused on designing customized services, which allowed them to gain access to a new target customer: schools. Although challenging, this experience was a key factor in the evolution of the firm given that providing high quality services to that specific target, led to an intense process of learning within the whole firm.

The entrepreneurs' decision to certificate quality and implement the process according to the ISO 9001, implied a new leap in the growth trajectory of the company. They continued to innovate and decided to undertake a diversification strategy creating new services (especially outdoor training) for new target markets (companies). Nowadays, the firm is still one of the main touristic attractions in the city in spite of the emergence of new competitors.

\section{Firm F}

$F$ is a cottage resort that comprises an urban area of $30,000 \mathrm{~m}^{2}$. Currently, the infrastructure includes a reception area, a spa, a restaurant, an indoor pool, an outdoor pool, and 18 cottages suited for 2, 4, 6 and 8 people. The firm started operating in 1997 and currently it has 13 employees (Table 6).

The growth path of this firm is associated with the different services that were added in response to the increase in the number of competitors. F was one of the first cottage resorts to be established in the city. At the beginning, competence was low. However, as the tourism sector gained importance in the local and national market, F's entrepreneurs were forced to improve their original offerings in order not to lose customers.

Firm F started operating in 1997 with a single cottage. The following year four more cottages were built. In this first phase, accommodation was the only service provided. Then, the entrepreneurs decided to increase the number of cottages and built a craft shop and a restaurant. This second stage was the longest period with only a few improvements in services. One of the reasons for this was the financial crisis of 2001-2002. Given the difficulty to invest in new cottages and facilities, the entrepreneurs focused on attracting new customers and inspiring loyalty from their regular customers. 
Table 6. Capabilities related to the growth of Firm F

\begin{tabular}{|c|c|c|c|c|}
\hline & $\begin{array}{l}\text { Phase I: } \\
\text { 1997-2000 }\end{array}$ & $\begin{array}{l}\text { Phase II: } \\
\text { 2000-2010 }\end{array}$ & $\begin{array}{l}\text { Phase III: } \\
\text { 2010-2013 }\end{array}$ & $\begin{array}{l}\text { Phase IV: } \\
2013 \text { - present }\end{array}$ \\
\hline $\begin{array}{l}\text { TO WHOM? } \\
\text { Customers and } \\
\text { Markets } \\
\text { How customers } \\
\text { and the tar- } \\
\text { get market have } \\
\text { changed over } \\
\text { time? }\end{array}$ & $\begin{array}{l}\text { Middle-class cu- } \\
\text { stomers main- } \\
\text { ly from Buenos } \\
\text { Aires }\end{array}$ & $\begin{array}{l}\text { High and mid- } \\
\text { dle-class custo- } \\
\text { mers mainly from } \\
\text { Buenos Aires }\end{array}$ & $\begin{array}{l}\text { High and mid- } \\
\text { dle-class custo- } \\
\text { mers mainly co- } \\
\text { uples from Bu- } \\
\text { enos Aires }\end{array}$ & $\begin{array}{l}\text { High and middle- } \\
\text { class customers } \\
\text { mainly couples } \\
\text { from Buenos } \\
\text { Aires, La Plata, } \\
\text { Mar del Plata and } \\
\text { other cities of the } \\
\text { province. }\end{array}$ \\
\hline $\begin{array}{l}\text { WHAT? } \\
\text { Products and se- } \\
\text { rvices } \\
\text { How has the sup- } \\
\text { ply changed over } \\
\text { time? }\end{array}$ & $\begin{array}{l}\text { Cottages for } 2 \\
\text { and } 4 \text { people }\end{array}$ & $\begin{array}{l}\text { Cottages, a craft } \\
\text { shop and a re- } \\
\text { staurant }\end{array}$ & $\begin{array}{l}\text { Cottages, suites, } \\
\text { restaurant, spa, } \\
\text { multipurpose } \\
\text { room }\end{array}$ & $\begin{array}{l}\text { Cottages, suites, } \\
\text { restaurant, spa, } \\
\text { multipurpose } \\
\text { room }\end{array}$ \\
\hline $\begin{array}{l}\text { HOW? } \\
\text { Business model } \\
\text { How has the busi- } \\
\text { ness model chan- } \\
\text { ged over time? }\end{array}$ & \multicolumn{2}{|c|}{$\begin{array}{l}\text { Independent touristic services. } \\
\text { Not based on horizontal or vertical } \\
\text { integration. } \\
\text { Own design and plan of the firm's } \\
\text { value chain. }\end{array}$} & $\begin{array}{l}\text { The owners rent } \\
\text { the business to a } \\
\text { private firm that } \\
\text { is in charge of the } \\
\text { operational acti- } \\
\text { vities. } \\
\text { The owners keep } \\
\text { the ownership } \\
\text { and develop ma- } \\
\text { nagerial activi- } \\
\text { ties. }\end{array}$ & $\begin{array}{l}\text { Independent to- } \\
\text { uristic services. } \\
\text { Not based on ho- } \\
\text { rizontal or verti- } \\
\text { cal integration. } \\
\text { Own design and } \\
\text { plan of the firm's } \\
\text { value chain. }\end{array}$ \\
\hline $\begin{array}{l}\text { WITH WHAT? } \\
\text { Key resources } \\
\text { and capabilities } \\
\text { What have been } \\
\text { the key resources } \\
\text { and capabilities } \\
\text { at each stage? }\end{array}$ & $\begin{array}{l}\text { Financial reso- } \\
\text { urces } \\
\text { Commercial ma- } \\
\text { nagement }\end{array}$ & $\begin{array}{l}\text { Financial reso- } \\
\text { urces } \\
\text { Capability to be } \\
\text { innovative } \\
\text { Institutional arti- } \\
\text { culation }\end{array}$ & $\begin{array}{l}\text { Commercial ma- } \\
\text { nagement } \mathrm{Ne}- \\
\text { tworking }\end{array}$ & $\begin{array}{l}\text { Capability to be } \\
\text { innovative }\end{array}$ \\
\hline $\begin{array}{l}\text { FOCUS } \\
\text { What was the } \\
\text { main concern in } \\
\text { each phase? }\end{array}$ & $\begin{array}{l}\text { Positioning in the } \\
\text { tourism market. } \\
\text { Local develop- } \\
\text { ment in the to- } \\
\text { urism sector. } \\
\text { Competition }\end{array}$ & $\begin{array}{l}\text { Products inno- } \\
\text { vation }\end{array}$ & $\begin{array}{l}\text { Lack of personal } \\
\text { motivation and } \\
\text { interest in con- } \\
\text { tinuing the busi- } \\
\text { ness }\end{array}$ & $\begin{array}{l}\text { Deciding and } \\
\text { planning the fu- } \\
\text { ture and continu- } \\
\text { ity of the firm }\end{array}$ \\
\hline
\end{tabular}

After this period, a third phase started with the building of "suites" cottages. This qualitative innovation meant a breakthrough for the company over its local and national competitors. Besides, a spa, a new reception area, and a multipurpose room aim at hosting institutional and private events were built. Despite all these improvements, the entrepreneurs went through a difficult time during this phase. They had lost the initial motivation and 
thought of selling or renting the cottage resort. Finally, they rented it to a private firm for a three-year period.

The forth phase began when the entrepreneurs decided to be in charge of the resort again. However, they had formulated a new strategy and a new business model in order to "enjoy" their business and not to lose motivation.

\section{Firm G}

$G$ is a cottage resort that offers accommodation and recreation for tourists. The company started operating in 2003 with only one cottage and currently has six cottages suited for 25 people (Table 7). Although this firmed originally emerged as part of the entrepreneur's lifestyle, he has turned it into a real business and has identified many opportunities to grow. In particular, the entrepreneur has adapted the business model to diversify the target market, for example, providing rental services of the restaurant and catering facilities for private events.

This firm started operating without any employee, only the founder entrepreneur. Once the firm had regular activity, employees were incorporated, depending on the work load. Considering the seasonally characteristic of the tourism sector, the entrepreneur could not afford to hire all the employees permanently. Thus, the number of employees has changed according to the customers' needs. Currently, the firm has six employees.

The evolution of this firm may be divided into three phases. The first period involved building all the cottages and providing services with the maximum available capacity. Then, an internal financial crisis inhibited innovations and the entrepreneur was not able to build any new cottage. The financial issues have always been the biggest difficulties in running the business. The entrepreneur has faced many problems to access funding and to manage the pressure of tax obligations. These conditions make the business no longer profitable.

However, the founder never gave up and continued working to improve services while trying to reduce fixed costs. Indeed, the last phase started when the firm started a recovery process. The entrepreneur had designed a different strategic to make it a profitable business. Thus, he cancelled the restaurant service and decided to use that place as a multipurpose room for private events. This decision is not directly related to the visitors' demands but the entrepreneur found a new business opportunity and made the effort to seize it. 
Table 7. Capabilities related to the growth of Firm $\mathrm{G}$

\begin{tabular}{|c|c|c|c|}
\hline & $\begin{array}{l}\text { Phase I: } \\
\text { 2003-2005 }\end{array}$ & $\begin{array}{l}\text { Phase II: } \\
\text { 2005-2011 }\end{array}$ & $\begin{array}{l}\text { Phase III: } \\
2011 \text { - present }\end{array}$ \\
\hline $\begin{array}{l}\text { TO WHOM? } \\
\text { Customers and } \\
\text { Markets } \\
\text { How customers and } \\
\text { the target market } \\
\text { have changed over } \\
\text { time? }\end{array}$ & $\begin{array}{l}\text { Moderate level of } \\
\text { occupation } \\
\text { Middle and high-class } \\
\text { customers mainly } \\
\text { from Buenos Aires }\end{array}$ & $\begin{array}{l}\text { Higher level of } \\
\text { occupation } \\
\text { Same type of } \\
\text { customers, although } \\
\text { varying according to } \\
\text { the seasons. }\end{array}$ & $\begin{array}{l}\text { Almost same level } \\
\text { of demand Types of } \\
\text { customers do not } \\
\text { suffer major changes } \\
\text { because the city } \\
\text { remains being a } \\
\text { relative high quality } \\
\text { destination }\end{array}$ \\
\hline $\begin{array}{l}\text { WHAT? } \\
\text { Products and services } \\
\text { How has the supply } \\
\text { changed over time? }\end{array}$ & $\begin{array}{l}\text { Cottages for couples } \\
\text { and families of up to } \\
\text { six members. }\end{array}$ & $\begin{array}{l}\text { Cottages and } \\
\text { restaurant services }\end{array}$ & $\begin{array}{l}\text { Cottages and } \\
\text { multipurpose room. } \\
\text { Restaurant services } \\
\text { are cancelled. }\end{array}$ \\
\hline $\begin{array}{l}\text { HOW? } \\
\text { Business model } \\
\text { How has the business } \\
\text { model changed over } \\
\text { time? }\end{array}$ & $\begin{array}{l}\text { The Enterprise was } \\
\text { originally thought as a } \\
\text { lifestyle. } \\
\text { Lack of planning and } \\
\text { design activities. } \\
\text { Available means }\end{array}$ & $\begin{array}{l}\text { Professionalization of } \\
\text { services } \\
\text { Implementation of a } \\
\text { management software } \\
\text { system Professional } \\
\text { advice } \\
\text { Regular staff training } \\
\text { programs }\end{array}$ & $\begin{array}{l}\text { Complementary } \\
\text { services and activities } \\
\text { are planned to add } \\
\text { value to the extant } \\
\text { services }\end{array}$ \\
\hline $\begin{array}{l}\text { WITH WHAT? } \\
\text { Key resources and ca- } \\
\text { pabilities } \\
\text { What have been the } \\
\text { key resources and } \\
\text { capabilities at each } \\
\text { stage? }\end{array}$ & $\begin{array}{l}\text { Financial resources to } \\
\text { star operating }\end{array}$ & $\begin{array}{l}\text { Employees } \\
\text { and services } \\
\text { professionalization } \\
\text { Innovative capacity } \\
\text { Institutional } \\
\text { coordination }\end{array}$ & $\begin{array}{l}\text { Ability to restructure } \\
\text { the business model to } \\
\text { face a major financial } \\
\text { crisis, without } \\
\text { reducing the level of } \\
\text { services provided }\end{array}$ \\
\hline $\begin{array}{l}\text { FOCUS } \\
\text { What was the main } \\
\text { concern in each } \\
\text { phase? }\end{array}$ & $\begin{array}{l}\text { Positioning in the } \\
\text { market }\end{array}$ & $\begin{array}{l}\text { Innovation in } \\
\text { products, processes, } \\
\text { and management }\end{array}$ & $\begin{array}{l}\text { Sustain profitability } \\
\text { rates } \\
\text { Services } \\
\text { diversification and } \\
\text { innovation } \\
\text { Positioning in a more } \\
\text { mature market }\end{array}$ \\
\hline
\end{tabular}

\section{Firm H}

$H$ is a cottage resort that began operating in 1998 (Table 8). The entrepreneurs started working on their own with only one cottage and now the firm has 10 cottages and 6 employees. The resort has accommodation for 42 people. Although the business may be considered a family business that was originally created as part of the entrepreneurs' lifestyle, nowadays they have a business vision and seek grow opportunities and high profitability. 
Table 8. Capabilities related to the growth of Firm $\mathrm{H}$

\begin{tabular}{|c|c|c|c|c|}
\hline & $\begin{array}{l}\text { Step I: } \\
\text { 1998-2001 }\end{array}$ & $\begin{array}{l}\text { Step II: } \\
\text { 2001-2004 }\end{array}$ & $\begin{array}{l}\text { Step III: } \\
\text { 2004-2010 }\end{array}$ & $\begin{array}{l}\text { Step IV: } \\
\text { 2010-2015 }\end{array}$ \\
\hline $\begin{array}{l}\text { TO WHOM? } \\
\text { Customers and } \\
\text { Markets } \\
\text { How customers } \\
\text { and the target } \\
\text { market have } \\
\text { changed over } \\
\text { time? }\end{array}$ & $\begin{array}{l}\text { Low level of } \\
\text { occupation } \\
\text { Middle-class } \\
\text { customers from } \\
\text { Buenos Aires } \\
\text { The city is } \\
\text { not strongly } \\
\text { positioned } \\
\text { as a touristic } \\
\text { destination. } \\
\text { Seasonal } \\
\text { demand }\end{array}$ & $\begin{array}{l}\text { Higher level of } \\
\text { occupation } \\
\text { Same type of } \\
\text { customers. } \\
\text { Seasonal } \\
\text { demand } \\
\text { The city starts } \\
\text { penetrating } \\
\text { the tourism } \\
\text { market after the } \\
\text { national crisis in } \\
2001 .\end{array}$ & $\begin{array}{l}\text { Higher level of } \\
\text { occupation } \\
\text { Middle-class } \\
\text { and upper class } \\
\text { customers } \\
\text { from Buenos } \\
\text { Aires and other } \\
\text { nearby cities. } \\
\text { Seasonal } \\
\text { demand }\end{array}$ & $\begin{array}{l}\text { Same level of } \\
\text { occupation. } \\
\text { Demand increases } \\
\text { in summer times } \\
\text { and holidays. } \\
\text { Demand becomes } \\
\text { steadier. }\end{array}$ \\
\hline $\begin{array}{l}\text { WHAT? } \\
\text { Products and } \\
\text { services } \\
\text { How has the } \\
\text { supply changed } \\
\text { over time? }\end{array}$ & $\begin{array}{l}\text { One single } \\
\text { cottage }\end{array}$ & Three cottages & $\begin{array}{l}\text { Seven cottages, } \\
\text { outdoor pool, } \\
\text { and reception } \\
\text { area. }\end{array}$ & $\begin{array}{l}\text { Ten cottages } \\
\text { Accommodation for } \\
42 \text { people. } \\
\text { Breakfast and } \\
\text { cleaning services. } \\
\text { Outdoor pool } \\
\text { Indoor pool } \\
\text { Spa } \\
\text { Playroom }\end{array}$ \\
\hline $\begin{array}{l}\text { HOW? } \\
\text { Business model } \\
\text { How has the } \\
\text { business model } \\
\text { changed over } \\
\text { time? }\end{array}$ & $\begin{array}{l}\text { The Enterprise } \\
\text { was originally } \\
\text { thought as a } \\
\text { lifestyle. } \\
\text { Business idea } \\
\text { not clearly } \\
\text { defined }\end{array}$ & $\begin{array}{l}\text { Business idea } \\
\text { not clearly } \\
\text { defined. } \\
\text { Financial and } \\
\text { operational } \\
\text { planning } \\
\text { activities. }\end{array}$ & $\begin{array}{l}\text { The business } \\
\text { plan becomes } \\
\text { more strategic- } \\
\text { orientated. } \\
\text { Focus on } \\
\text { customer } \\
\text { satisfaction. }\end{array}$ & $\begin{array}{l}\text { Customer } \\
\text { satisfaction. } \\
\text { Customer loyalty } \\
\text { High quality } \\
\text { standards in } \\
\text { services. } \\
\text { Advertising in social } \\
\text { networks such as } \\
\text { Trip advisor and } \\
\text { Facebook. }\end{array}$ \\
\hline $\begin{array}{l}\text { WITH WHAT? } \\
\text { Key resources } \\
\text { and capabilities } \\
\text { What have been } \\
\text { the key resources } \\
\text { and capabilities } \\
\text { at each stage? }\end{array}$ & $\begin{array}{l}\text { Financial } \\
\text { resources to } \\
\text { start operating }\end{array}$ & $\begin{array}{l}\text { Financial } \\
\text { resources to } \\
\text { improve the } \\
\text { services supply } \\
\text { Focus on } \\
\text { developing } \\
\text { qualified human } \\
\text { resources }\end{array}$ & $\begin{array}{l}\text { Funding from } \\
\text { different } \\
\text { investors }\end{array}$ & $\begin{array}{l}\text { Financial resources } \\
\text { Human resources. } \\
\text { Staff training } \\
\text { programs } \\
\text { Innovative capacity } \\
\text { Professionalization }\end{array}$ \\
\hline $\begin{array}{l}\text { FOCUS } \\
\text { What was the } \\
\text { main concern in } \\
\text { each phase? }\end{array}$ & $\begin{array}{l}\text { Market } \\
\text { positioning. }\end{array}$ & $\begin{array}{l}\text { Market } \\
\text { positioning }\end{array}$ & $\begin{array}{l}\text { Achieve greater } \\
\text { accommodation } \\
\text { capacity } \\
\text { Increase } \\
\text { incomes to } \\
\text { invest in the } \\
\text { business } \\
\text { Product } \\
\text { innovation }\end{array}$ & $\begin{array}{l}\text { Achieve greater } \\
\text { accommodation } \\
\text { capacity } \\
\text { Product innovation } \\
\text { Human resources } \\
\text { management }\end{array}$ \\
\hline
\end{tabular}


The firm's growth involved a gradual process associated to the number of cottages and the services that were provided. Since the beginning, the entrepreneurs decided to incorporate one cottage per year approximately in order to improve services and be financially balanced. Besides, the entrepreneurs emphasized that providing high quality services is the key to survive in such a competitive market and that they have always focused on client satisfaction.

The first phase includes the beginning of the activity and the first access to customers. Then, we identified a new phase after the financial crisis of 2001, which influenced directly into the business. Due to the crisis, the entrepreneurs were forced to sell their home in order to get cash to cancel a loan. Besides, the crisis had a strong impact on the tourism activity in general. Fortunately, people that were not able to travel abroad, decided to travel to Tandil. Thus, Tandil became a touristic destination in demand.

After the crisis, in a third phase firm $\mathrm{H}$ incorporated new services. Specifically, the outdoor pool. In this period, the entrepreneurs focused on customers' needs and become more strategic- orientated. Although the entrepreneurs considered their business as a lifestyle, they realized that they had to reformulate the strategy and plan their growth trajectory. This change implied the start of a new phase and during the last five years the firm has incorporated an indoor pool, a spa, and a playroom. Furthermore, three new cottages have been built. Currently, the entrepreneurs focus on providing high quality services instead of expanding the accommodation capacity.

\section{Empirical cross case analysis}

As mentioned above, we conducted a comparative analysis across cases, based on Teece's framework of DC and its microfoundations. Besides, we compared growth paths across firms and economic sectors (Tables 9 and 10). 
Table 9. Cross-case analysis for enterprise of software and informatics services

\begin{tabular}{|c|c|c|c|c|}
\hline \multirow[b]{2}{*}{ Core Concept } & \multicolumn{4}{|c|}{ Empirical Themes and Illustrative Data } \\
\hline & Case A & Case B & Case C & Case D \\
\hline Growth Path & Gradual & Gradual & Accelerated & Accelerated \\
\hline Sensing & Moderate & Moderate & Strong & Very Strong \\
\hline $\begin{array}{l}\text { Analytical Systems } \\
\text { and individual ca- } \\
\text { pacities to learn } \\
\text { and to sense, filter, } \\
\text { shape and calibra- } \\
\text { te opportunities }\end{array}$ & $\begin{array}{l}\text { Key factor: social and } \\
\text { personal contacts and } \\
\text { networking strategy } \\
\text { "(...) individuals in the } \\
\text { software industry are } \\
\text { so connected....that the } \\
\text { most successful com- } \\
\text { mercial strategy is ne- } \\
\text { tworking...no adverti- } \\
\text { sing is required." }\end{array}$ & $\begin{array}{l}\text { Key factor: } \\
\text { Initial identification of } \\
\text { business opportunity in } \\
\text { a crisis context } \\
\text { Restricted capacity to } \\
\text { operate because of the } \\
\text { dependence on the he- } \\
\text { adquarter } \\
\text { "Nowadays we are try- } \\
\text { ing to penetrate new } \\
\text { markets, and more spe- } \\
\text { cifically, to sell to the } \\
\text { US market... that is the } \\
\text { only way to compete." }\end{array}$ & $\begin{array}{l}\text { Key factor: } \\
\text { Entrepreneurial orien- } \\
\text { tation } \\
\text { Entrepreneur's perso- } \\
\text { nal and professional } \\
\text { contacts } \\
\text { Networking } \\
\text { “(...) many people have } \\
\text { specific local knowled- } \\
\text { ge.... And solutions and } \\
\text { decisions are likely to } \\
\text { be biased.... My orien- } \\
\text { tation has always been } \\
\text { biased towards the US } \\
\text { industry”. }\end{array}$ & $\begin{array}{l}\text { Key factor: } \\
\text { Participation and inten- } \\
\text { sive mentoring from } \\
\text { business accelerators } \\
\text { programs. } \\
\text { Market Research } \\
\text { "In the business acce- } \\
\text { lerator program (Tech- } \\
\text { stars) mentors attac- } \\
\text { ked our business idea } \\
\text { and business model ba- } \\
\text { sed on solid arguments } \\
\text { (...) so we started analy- } \\
\text { zing the American mar- } \\
\text { ket.... }\end{array}$ \\
\hline Seizing & Moderate & Moderate/Low & Strong & Strong \\
\hline $\begin{array}{l}\text { Enterprise struc- } \\
\text { tures, procedures, } \\
\text { designs and incen- } \\
\text { tives for seizing } \\
\text { opportunities }\end{array}$ & $\begin{array}{l}\text { Key factor: } \\
\text { Technological training } \\
\text { and specialization } \\
\text { "(...) For us, the most } \\
\text { important difficulty is } \\
\text { the commercial deve- } \\
\text { lopment of the busi- } \\
\text { ness ... we have to be } \\
\text { creative...Given that we } \\
\text { had no training or expe- } \\
\text { rience in commercial } \\
\text { activities, we decided } \\
\text { to do the MBA. }\end{array}$ & $\begin{array}{l}\text { Key factor: } \\
\text { Joint growth of the } \\
\text { business group from } \\
\text { which the firm de- } \\
\text { pends on. } \\
\text { Difficulty in exploiting } \\
\text { opportunities not inc- } \\
\text { luded in the business } \\
\text { group strategy that is } \\
\text { formulated by the he- } \\
\text { adquarters. } \\
\text {.Here we develop pro- } \\
\text { ducts that are sold } \\
\text { worldwide. Here we are } \\
\text { in charge of the tech- } \\
\text { nical activities: the so- } \\
\text { ftware development } \\
\text { and technical sup- } \\
\text { port ...and there (Spa- } \\
\text { in) they have speciali- } \\
\text { zed in commercial ma- } \\
\text { nagement and contact } \\
\text { with customers around } \\
\text { the world. } \\
\text { (...)We have many si- } \\
\text { gnificant limitations in } \\
\text { making our own deci- } \\
\text { sions regarding certa- } \\
\text { in business issues... we } \\
\text { are restricted.... Besi- } \\
\text { des, we do not have di- } \\
\text { rect contact with the } \\
\text { market and we lack } \\
\text { essential commer- } \\
\text { cial skills }\end{array}$ & $\begin{array}{l}\text { Key factor: } \\
\text { Organizational culture } \\
\text { and knowledge mana- } \\
\text { gement } \\
\text { "We differentiate from } \\
\text { our competitors in how } \\
\text { we do things. We have } \\
\text { much less processes, } \\
\text { documents, and tradi- } \\
\text { tional certifications. On } \\
\text { the contrary, we en- } \\
\text { courage people and } \\
\text { things to keep as closer } \\
\text { as possible. We foster } \\
\text { members to tell stories, } \\
\text { to share spaces, ideas, } \\
\text { and opinions. We want } \\
\text { to share idiosyncrasy } \\
\text { and build a real organi- } \\
\text { zational culture...stra- } \\
\text { tegies are almost the } \\
\text { same.... the key is inter- } \\
\text { personal relationships }\end{array}$ & $\begin{array}{l}\text { Key factor: } \\
\text { Managerial skills and } \\
\text { capabilities of Entrepre- } \\
\text { neurial team } \\
\text { Strategic partnerships } \\
\text { Managerial, financial, } \\
\text { and operational sup- } \\
\text { port } \\
\text { "You can always go to } \\
\text { the market and validate } \\
\text { your product or servi- } \\
\text { ce, even before having } \\
\text { the final product or se- } \\
\text { rvice ready for distribu- } \\
\text { tion. You can talk to po- } \\
\text { tential customers, part- } \\
\text { ners, and stakeholders } \\
\text { and verify the business } \\
\text { 'feasibility at least at a } \\
\text { minimum scale to then } \\
\text { extrapolate the results. } \\
\text { And that is what we did } \\
\text { (...) We were forced to } \\
\text { increase the working } \\
\text { team and develop part- } \\
\text { nerships with American } \\
\text { companies, which co- } \\
\text { uld provide us novel lo- } \\
\text { gistic skills. All this invo- } \\
\text { Ived much more organi- } \\
\text { zational activities. Our } \\
\text { advisors and investors } \\
\text { were central to achie- } \\
\text { ve all this. }\end{array}$ \\
\hline
\end{tabular}




\begin{tabular}{|c|c|c|c|c|}
\hline \multirow[b]{2}{*}{$\begin{array}{l}\text { Managing threats } \\
\text { and resource } \\
\text { reconfiguration }\end{array}$} & \multicolumn{4}{|c|}{ Empirical Themes and Illustrative Data } \\
\hline & Moderate/Low & Moderate/Low & Strong & Moderate \\
\hline $\begin{array}{l}\text { Continuous align- } \\
\text { ment and realign- } \\
\text { ment of specific } \\
\text { tangible and intan- } \\
\text { gible assets }\end{array}$ & $\begin{array}{l}\text { Key factor: } \\
\text { Specialization in BIG } \\
\text { DATA technology. } \\
\text { Extensive learning pro- } \\
\text { cesses. } \\
\text { Expansion and positio- } \\
\text { ning in the US market. } \\
\text { "(...) It is extremely im- } \\
\text { portant for us to have } \\
\text { an office in the US mar- } \\
\text { ket. We are seeking for } \\
\text { a specialization path to } \\
\text { get out of the outsour- } \\
\text { ced development servi- } \\
\text { ce market, where any- } \\
\text { one enters and compe- } \\
\text { tes without adding va- } \\
\text { lue. A kind of speciali- } \\
\text { zation which does not } \\
\text { involve increasing the } \\
\text { number of people to } \\
\text { escalate and grow...be- } \\
\text { cause that is a clear li- } \\
\text { mitation ...That would } \\
\text { enable us to specialize } \\
\text { in specific technologies } \\
\text { that require extensive } \\
\text { learning processes...and } \\
\text { that does create a real } \\
\text { barrier to market entry } \\
\text { and competition". }\end{array}$ & $\begin{array}{l}\text { Key factor: } \\
\text { Adaptation to the he- } \\
\text { adquarters 'conditions } \\
\text { and limitations. } \\
\text { It is unlikely for the firm } \\
\text { to decide and formu- } \\
\text { late an independent } \\
\text { strategy. } \\
\text { "Today we prioritize qu- } \\
\text { ality rather than costs } \\
\text { because the differen- } \\
\text { ce in costs between Ar- } \\
\text { gentina and Spain is al- } \\
\text { most nonexistence.... } \\
\text { there may be differen- } \\
\text { ce between Spain and } \\
\text { US, but that is not our } \\
\text { case.... However, at the } \\
\text { beginning, selling high } \\
\text { quality products and } \\
\text { services in a country fa- } \\
\text { cing crisis was almost } \\
\text { impossible...but today } \\
\text { our company has } 7 \text { or } 8 \\
\text { years of experience and } \\
\text { it has developed many } \\
\text { international successful } \\
\text { projects". }\end{array}$ & $\begin{array}{l}\text { Key factor: Experien- } \\
\text { ce- based learning } \\
\text { "(...) we realized that } \\
\text { the media industry was } \\
\text { changing towards digi- } \\
\text { talization and automa- } \\
\text { tion....so we decided } \\
\text { to focus on providing } \\
\text { services to large me- } \\
\text { dia companies...but the } \\
\text { evolution of the mar- } \\
\text { ket was slower than we } \\
\text { expected and we never } \\
\text { managed to be a profi- } \\
\text { table organization. We } \\
\text { failed to find the ade- } \\
\text { quate scalable busi- } \\
\text { ness model although } \\
\text { we struggled to deve- } \\
\text { lop mechanisms to at- } \\
\text { tract customers from } \\
\text { the media industry....so } \\
\text { we sold our intellectual } \\
\text { property to a US com- } \\
\text { pany. After that, we re- } \\
\text { configured our resour- } \\
\text { ces and started a new } \\
\text { company based on our } \\
\text { previous experiences, } \\
\text { knowledge, and tra- } \\
\text { ining orientated to- } \\
\text { wards high quality se- } \\
\text { rvices" }\end{array}$ & $\begin{array}{l}\text { Key factor: } \\
\text { Learning based on en- } \\
\text { trepreneurs 'own expe- } \\
\text { rience and others } \\
\text { 'experience. } \\
\text { Important changes in } \\
\text { business model to- } \\
\text { wards the integration } \\
\text { between on-line sa- } \\
\text { les and the customers } \\
\text { 'experiences through } \\
\text { off-line sales } \\
\text { "We decided to chan- } \\
\text { ge from a marketplace } \\
\text { model focused on sel- } \\
\text { ling online, towards a } \\
\text { more sustainable mo- } \\
\text { del based on service } \\
\text { layer...which is superior } \\
\text { because it involves si- } \\
\text { gnificant logistic chal- } \\
\text { lenges and also consi- } \\
\text { ders the off-line expe- } \\
\text { riences of customers". }\end{array}$ \\
\hline
\end{tabular}




\section{Table 10. Cross-case analysis for enterprise of turism}

\begin{tabular}{|c|c|c|c|c|}
\hline \multirow[b]{2}{*}{ Core Concept } & \multicolumn{4}{|c|}{ Empirical Themes and Illustrative Data } \\
\hline & Case $\mathrm{E}$ & Case F & Case G & Case H \\
\hline $\begin{array}{l}\text { Growth Path } \\
\text { (Gradual vs. } \\
\text { Accelerated) }\end{array}$ & Gradual & Gradual & Gradual & Gradual \\
\hline Sensing & Moderate & Moderate & Moderate/Low & Moderate/Low \\
\hline $\begin{array}{l}\text { Analytical Systems } \\
\text { and individual } \\
\text { capacities to learn } \\
\text { and to sense, } \\
\text { filter, shape } \\
\text { and calibrate } \\
\text { opportunities }\end{array}$ & $\begin{array}{l}\text { Key factor: } \\
\text { Information } \\
\text { for identifying } \\
\text { opportunities from } \\
\text { customer surveys. } \\
\text { Social and professional } \\
\text { circles } \\
\text { Relationship with } \\
\text { suppliers } \\
\text { Permanent staff } \\
\text { training } \\
\text { "When we started } \\
\text { providing this all- } \\
\text { inclusive kind of service } \\
\text { in our camps, including } \\
\text { accommodation, food, } \\
\text { and outdoor activities, } \\
\text { there was no other } \\
\text { place to offer the same } \\
\text { services. And as time } \\
\text { went by, we were } \\
\text { able to identify new } \\
\text { business opportunities. } \\
\text { And since a couple } \\
\text { of years ago our } \\
\text { main target segment } \\
\text { started comprising } \\
\text { high performance } \\
\text { sports teams and } \\
\text { large companies, } \\
\text { demanding both our } \\
\text { traditional recreational } \\
\text { activities and new } \\
\text { professionalized } \\
\text { services.. }\end{array}$ & $\begin{array}{l}\text { Key factor: } \\
\text { Deep knowledge about } \\
\text { the tourism industry } \\
\text { and customers' needs. } \\
\text { Entrepreneurial } \\
\text { orientation } \\
\text { Active participation } \\
\text { in local and regional } \\
\text { institutional networks } \\
\text { directly linked to } \\
\text { tourism activities. } \\
\text { "I believe that } \\
\text { identifying } \\
\text { opportunities has to do } \\
\text { with my personality... } \\
\text { but of course my } \\
\text { education and training } \\
\text { are important too, } \\
\text { clearly. (...), And the } \\
\text { most important thing } \\
\text { is to keep permanent } \\
\text { contact with customers. } \\
\text { (...) } \\
\text { Regarding my } \\
\text { connection with } \\
\text { institutions within the } \\
\text { tourism industry, I have } \\
\text { actively participated } \\
\text { in both local and } \\
\text { national institutions. } \\
\text { Networking is a must". }\end{array}$ & $\begin{array}{l}\text { Key factor: } \\
\text { Direct contact with } \\
\text { customers. } \\
\text { Active participation } \\
\text { in local and regional } \\
\text { institutional networks } \\
\text { directly linked to } \\
\text { tourism activities } \\
\text { "Opportunities } \\
\text { always arise from } \\
\text { direct contact and } \\
\text { communications with } \\
\text { customers, which } \\
\text { can be formally or } \\
\text { informally established... } \\
\text { we make surveys." } \\
\text {.. (..) you have to } \\
\text { participate because } \\
\text { that way you can } \\
\text { generate professional } \\
\text { and commercial links, } \\
\text { and even friendship, } \\
\text { with your own } \\
\text { competitors...and } \\
\text { many times informal } \\
\text { meetings are good to } \\
\text { generate interesting } \\
\text { debates and exchange } \\
\text { different point of views } \\
\text { and share experiences... } \\
\text { and new ideas are likely } \\
\text { to emerge.. And we } \\
\text { help each other...that } \\
\text { is what cooperation } \\
\text { means.. }\end{array}$ & $\begin{array}{l}\text { Key factor: } \\
\text { Direct contact with } \\
\text { customers. } \\
\text { Active participation } \\
\text { in local and regional } \\
\text { institutional networks } \\
\text { directly linked to } \\
\text { tourism activities } \\
\text { "(...) Our firm has } \\
\text { experienced gradual } \\
\text { growth...being here all } \\
\text { the time, and living in } \\
\text { the same place that our } \\
\text { customers, they enjoy } \\
\text { talking and expressing } \\
\text { their opinion about } \\
\text { how they feel, what } \\
\text { they expected, and } \\
\text { what things would be } \\
\text { positive to change..... } \\
\text { And that allows us to } \\
\text { enhance our services } \\
\text { and grow. We are } \\
\text { very aware of how } \\
\text { customers feel and they } \\
\text { appreciate that too. " } \\
\end{array}$ \\
\hline Seizing & Strong & Moderate & Moderate/Low & Moderate/Low \\
\hline $\begin{array}{l}\text { Enterprise } \\
\text { structures, } \\
\text { procedures, } \\
\text { designs and } \\
\text { incentives } \\
\text { for seizing } \\
\text { opportunities }\end{array}$ & $\begin{array}{l}\text { Key factor: } \\
\text { Availability of financial } \\
\text { resources. } \\
\text { Professional structure } \\
\text { ISO quality certification } \\
\text { including all the } \\
\text { organizational } \\
\text { processes, from service } \\
\text { design to marketing } \\
\text { strategies. } \\
\text { Permanent evaluation } \\
\text { from customers } \\
\text { "We keep training all } \\
\text { the time... we attend } \\
\text { external or in-house }\end{array}$ & $\begin{array}{l}\text { Key factor: } \\
\text { Availability of financial } \\
\text { resources to make } \\
\text { all the necessary } \\
\text { investments. } \\
\text { Design of a platform to } \\
\text { provide superior quality } \\
\text { services. } \\
\text { "We are risk averse } \\
\text { so we dedicate too } \\
\text { much time to think } \\
\text { about everything very } \\
\text { carefully... we do lot }\end{array}$ & $\begin{array}{l}\text { Key factor: } \\
\text { Limited not } \\
\text { professional } \\
\text { organizational structure } \\
\text { Scarce financial } \\
\text { resources } \\
\text { "At the beginning there } \\
\text { was only one employee } \\
\text { and then we hired } \\
\text { more staff as it was } \\
\text { necessary depending } \\
\text { on the demand, which } \\
\text { is extremely seasonal. } \\
\text { Currently, there are six } \\
\text { part-time employees... }\end{array}$ & $\begin{array}{l}\text { Key factor: } \\
\text { Availability of financial } \\
\text { resources } \\
\text { Staff training } \\
\text { Communication } \\
\text { "(...) regarding funding, } \\
\text { we have obtained } \\
\text { many bank credits } \\
\text { that enable us to } \\
\text { make investments and } \\
\text { improve our supply } \\
\text { (...) We also received } \\
\text { money from private } \\
\text { investors and that } \\
\text { boosted the business.. }\end{array}$ \\
\hline
\end{tabular}


programs."

(...) certifying was not as difficult as many people believe. We already had many control and standard processes and the organizational culture was prepared for those changes... we only needed to adapt the way of doing certain things. Ours was the first company in South America to achieve that although we spend almost every day together, we dedicate time to debate and create a specific environment to talk business." of planning. Indeed,

but although we are few people we still keep and social capital are things organized and so there is a Director, an executive assistant, and a management team. Besides, operational activities are also divided into cleaning, cooking, and maintenance."

(...) there are lots of things to do to improve our services... but the problem is to maintain profitability when increasing".

Managing threats and resource reconfiguration

Continuous alignment and realignment of specific tangible and intangible assets

$\begin{array}{lll}\text { Moderate } \quad \text { Moderate Low } & \text { Moderate/Low }\end{array}$

Key factor:

Diversification in the services supply

"We have made many changes ... for example, we cancelled central in this kind of invest in staff training programs. general meetings for every one month. Communication is an essential resource." certification. costs are constantly

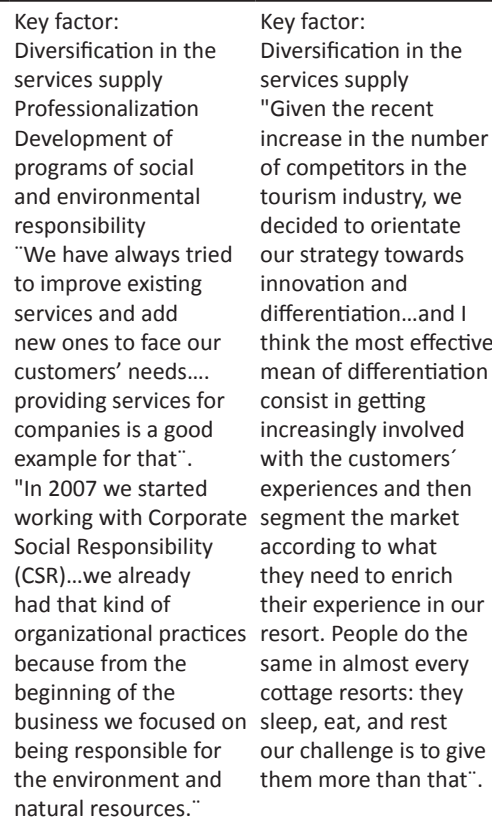
the services from the restaurant that were no longer profitable activities. We regularly

(...) and we have the whole staff at least and decided to rent the place to private events as a multipurpose room. Now we have a new "business" with new customers and another source of income."

Key factor:
Diversification in the
services supply
"Competition is an
important matter to
the survival of the
firm...there are many
problems with the
entry barriers in the
local market....there
are not any...too
many new entrants
that easily attract and
absorb clients providing
modern services,
which are less likely to
be provided by older
companies.

\section{DISCUSSION}

Overall, we identified some common results regarding DC across all the cases. However, firms engage in different types of growth trajectories and that influences the type of skills that firms decide to develop. Besides, there are different growth patterns related to specific industries and to specific firms. Furthermore, firms have different expectations related to growth depending on the stage of their life cycle. Strategic priorities also differ between firms. 
In the present study we analyzed how growth paths differ between the sectors and how DC differ between SMEs within the same industry. Given that results were analyzed based on Teece's theoretical model of DC (2007), we identified industry-specific and common factors involved in the development of DC. We also identified that although all the firms generated some DC to grow, they applied different mechanisms, as shown in Table 9 (Cross Case Analysis between firms in the Software sector) and Table 10 (Cross Case Analysis between firms in the Tourism Sector).

With regard to the capability to sense opportunities, this identification resulted to be closely linked to the entrepreneurs and, specifically, to their entrepreneurial orientation, personal and professional contacts, and networks. This is because market and industry information is the key to identify business opportunities and be competitive. Thus, entrepreneurs contact other participants to obtain this knowledge and understand the business ecosystem, and to gain experience in making strategic decisions. Additionally, in order to obtain market information, the majority of the entrepreneurs highlighted the importance of keeping close contact with customers (particularly in tourism firms) and networking.

At the individual level, based on Teece's framework, we interpreted the role of entrepreneurs' managerial skills, particularly, in younger companies, in which individual capabilities are extremely important. Indeed, at the startup stage, firms are based mainly on entrepreneurs 'skills. On the contrary, established companies mainly focus on organizational processes and routines and the ability of the management team. In relation to this, Teece concluded that the ability to recognize opportunities depends on the capabilities of individuals, and, specifically, on knowledge about customers' needs (Teece, 2007).

To conclude, other factors also influence the process of identifying opportunities, such as the changing conditions of the macroeconomic context in which companies operate, which requires flexibility, permanent reconfiguration of business strategies, and the search for new markets for firms to compete. This conditions lead entrepreneurs to develop entrepreneurial capabilities in terms of environmental monitoring and strategic planning given that they are asked to design alternative business models and strategies. Firms $A$ and $D$ are good examples of the reorientation of the business strategy.

The capability to seize opportunities varies depending on the activity and the growth path of each firm. Many entrepreneurs identified or sensed opportunities but failed to seize or exploit them, particularly in the SSI sector, because of the difficulty in identifying the needs of the target market. This is primarily attributed to the lack of strategic management skills. Unfortunately, 
entrepreneurs do not realize about this problem until they face grow opportunities and realized they do not are prepared for that challenge (firms $A$ and $B)$.

Firms that experienced gradual growth identified managerial skills as fundamental factors and the entrepreneurs of SSI firms concluded that their main weaknesses were associated to the lack of managerial skills. On the contrary, firms with accelerated growth, focused on a specific factor: organizational culture and interpersonal relationships. Flexibility and knowledge management are considered competitive advantages in the SSI sector (firm C) as well as working teams and strategic alliances (firm D).

Firms in the tourism sector demonstrated to face different problems and to focus on the availability of financial resources and the certification of quality standards. These aspects are particularly relevant for tourism firms. Whenever entrepreneurs decided to expand their services and make investment decisions, they considered both the potential opportunities and the available resources. Therefore, this is a fundamental capability for tourism firms.

Business model is also relevant in this stage. The kind of business model may have a strong impact on the firm's capacities. For example, firm B depends exclusively from a Spanish business group and that limits the action and motivation of the entrepreneurs. In many cases, the local firm had sensed opportunities to grow but was not able to make any decision and they lost them. So, it is important for the firms to remain alert and detect opportunities but also to transform customers' needs in new products or services (Teece, 2007). The decision-making process also influences the firm's possibilities to seize business opportunities, as well as networking activities, that provide access to resources and capabilities and accelerate learning processes.

With regard to the capability to manage threats and orchestrate resources, firms that experienced gradual growth based their capabilities on technological specialization and learning; and the capacity to adapt to environmental conditions. Particularly, learning from past experience in the sector, that allows entrepreneurs to visualize market changes, is critical to the development of skills related to accelerated growth in SSI companies.

Teece (2007) argues that the key to sustain growth is the ability to recombine resources and organizational structures as the company grows and markets and technologies change. In this context, it is important not only to identify the objective conditions of the environment, but also the subjective perception of entrepreneurs. In this aspect, we identified certain common concerns regarding the development of the businesses.

In the SSI sector, the most important concern is linked to the progressive loss of competitiveness of local companies in international markets, derived 
from the sustained increase in labor costs (which in this sector represent the largest item in their cost structure). Besides, the international financial crisis is pushing down wages (particularly in European countries). Thus, local firms are forced to re-orientate their strategies and resources towards technical and commercial specialization and higher differentiation to reach more profitable markets.

Furthermore, in the software industry, in particular, inflation is another important factor that further hinders the scenario for companies to sustain competitive advantages. Local firms have serious difficulties in transferring the increase in costs to final prices, which are internationally determined. Besides, firms compete do not compete for customers but for qualified human resources, which are scarce resource and therefore are strongly disputed by companies.

In the tourism industry, to face change and be competitive the key factors are the development of managerial skills orientated towards the diversification of the services provided and the formulation of innovative strategies to differentiate from competitors, such as social responsibility programs and environmental programs.

Additionally, the absorptive capacity is a critical tool for touristic firms to face new environmental conditions and reformulate their strategic orientations. Besides, firms improve efficiency and quality of their services applying mechanisms or agile methodologies to analyze, repeat and experiment tasks to improve performance in the shortest time possible, and to optimize response times and continually validate customers' requirement through a more direct contact at different stages of the product development. This process of repetition and experimentation enables companies to generate necessary organizational learning.

Finally, we emphasize that the three types of DC should be analyzed together, because firms need all of them to grow. Based on our analysis, DC were developed in a context of significant openness to learning, and where experimentation and trial and error played a prominent role. The integration and reconfiguration of activities, resources, and skills did not involve a strategically planned process, but rather an emergent process, strongly motivated by the entrepreneurs' ability to identify trends and changes in the environmental conditions, which are mainly uncertain.

This is an interesting empirical finding that contradicts current literature that focuses on "how" companies grow, or "how should firms grow", identifying "better" or more sophisticated planning processes. By contrast, we identify Sarasvathy' s idea (2001) about how "exposure to experiences" turns out to be a central element to develop high value learning to boost the growth in SMEs. 


\section{CONCLUSION}

This study focuses on the investigation of specific capabilities associated with the growth of SMEs and shed light on some of the topics of DC that remained little explored. Specifically, we combine the literature on Entrepreneurship and Strategic Management to explore the strategic decisions that SMEs implement to grow in developing countries, and their results. We also provide empirical evidence on the role of DC in the growth of SMEs, specifically, comparing two important economic sectors.

Furthermore, the present study improves the understanding of DC, analyzing how SMEs create, identify and seize opportunities; and identify which specific capabilities led small and medium-sized to gain a sustainable market position and also to grow. Another contribution of this work is the empirical testing of theoretical constructs, particularly, applying a qualitative analysis that allowed us to identify the key aspects of the process of development of DC in SMEs. As a consequence, this study contributes to entrepreneurs and managers to understand the basis for firm sustainability based on specific capabilities associated to firm growth; and to policy makers to understand the dynamics of SMEs and obtain empirical evidence to formulate policies that foster firm growth. Furthermore, the present study proves that DC 's framework may be applied in the analysis of SMEs in developing countries.

Based on the cases, it was found that all the companies had developed capabilities associated with sensing and seizing opportunities, and reconfiguring resources. However, these capabilities differed between cases, depending on the evolutionary paths of each business. This explanation of the importance of DC in the different phases or "jumps" in the growth path is another contribution of the present study.

Besides, our findings suggest that the process of identifying business opportunities implies an emergent process rather than a predetermined strategic decision. We also conclude that the identification of opportunities is not the most important threat, since companies have successfully recognized and evaluated important business opportunities with their existing resources and capabilities. On the contrary, firms faced many difficulties in seizing opportunities and adapting to changes.

To conclude, the main limitations of this study are the lack of analysis of other factors associated with DC and the lack of delineation in the scope of the capabilities addressed. Besides, results are drawn from a limited number of cases (8), and these companies are at different stages of development. These important issues should be considered for future research on DC. 


\section{References}

Ambrosini, V. \& Bowman, C. (2009). What are dynamic capabilities and are they a useful construct in strategic management? International Journal of Management Reviews, 11(1), 29-49.

Andersen, D. R., \& Burnham, K. P. (2002). Avoiding pitfalls when using information-theoretic methods. The Journal of Wildlife Management, 96(3), 912-918.

Augier, M. \& Teece D.J. (2008). Strategy as evolution with design: the foundations of dynamic capabilities and the role of managers in the economic system. Organization Studies, 29(8-9), 1187-1208.

Backman, J. (1998). Rapporter och uppsatser. Lund: Studentlitteratur

Bryman, A. \& Bell, E. (2007). Business research methods, Oxford: Oxford University Press.

Cámara de Empresas de Software y Servicios Informáticos de la República Argentina - CESSI (http://www.cessi.org.ar/). Reporte anual del sector de software y servicios informáticos de la Repúblic a Argentina Año 2014.

Carattoli, M., D'Annunzio, C. \& Dupleix, D. (2014). Development of dynamic capabilities in small and medium-sized enterprises in the software sector. SMEs, Innovation, and Development, 2(1), 2-31.

Cavusgil, E., Seggie, S.H. \& Talay M.B. (2007). Dynamic capabilities view: foundations and research agenda. Journal of Marketing Theory and Practice, 15(2), 159-166.

Charles, G. (2009). Competitive advantage in small and medium-scale enterprises: A resource-based analysis of Tanzanian family and nonfamily firms. Doctoral Dissertation. Dar es Salaam: University of Dar es Salaam.

Creswell, J. W. (2007). Qualitative inquiry and research design: choosing among five approaches. Thousand Oaks, CA: Sage.

D’Annunzio C., Carattoli M., \& Dupleix, D. (2014). Development of dynamic capabilities in small and medium-sized enterprises in the tourism sector. XIXo Annual Meeting of Red Pymes Mercosur. Instituto de Economía, Universidad Estadual de Campinas, Brazil. September, 2014.

Danneels, E. (2011). Trying to become a different type of company: dynamic capability at Smith Corona. Strategic Management Journal, 32, 1-31.

D'Annunzio, C., Rébori, A. \& Bricker, A. (2008). Empresas Tecnológicas del Sector de Software y Servicios Informáticos (SSI): análisis y caracterización. Artículo presentado en la XIII Reunión Anual de la Reunión Anual Red PyMEs MERCOSUR, San Martín, Prov. de Buenos Aires, septiembre.

Davidsson, P. (2004). Researching entrepreneurship. New York: Springer

Dutta, D. K., \& Thornhill, S. (2008). The evolution of growth intentions: toward a cognition-based model. Journal of Business Venturing, 23(3), 307-332.

Eisenhardt, K. M. \& Martin, J. (2000). Dynamic capabilities: What are they? Strategic Management Journal 21, 10/11, 1105-1121.

Eisenhardt, K. M. (1989). Building theories from case study research. Academy of Management Review, 14(4), 532-550. 
Ethiraj, S. K., Kale, P., Krishnan, M. S. \& Singh, J. V. (2005). Where do capabilities come from and how do they matter? A study in the software services industry. Strategic Management Journal, 26(1), 25-45.

Feiler, P., \& Teece, D. (2014). Case study, dynamic capabilities and upstream strategy: Supermajor EXP. Energy Strategy Reviews, 3, 14-20.

Gartner, W. B. (1985). A conceptual framework for describing the phenomenon of new venture creation. Academy of Management Review, 10(4), 696706.

Hall, C. M. (2009). Innovation and tourism policy in Australia and New Zealand: never the twain shall meet? Journal of Policy Research in Tourism, Leisure and Events, 1(1), 2-18.

Hall, C.M. \& Williams, A. M. (2008). Tourism and innovation. London: Routledge.

Helfat, C. \& Peteraf, M. (2003). The dynamic resource-based view: capability lifecycles. Strategic Management Journal, 24(10), 997-1010.

Helfat, C. \& Peteraf, M. (2009). Understanding dynamic capabilities: progress along a developmental path. Strategic Organization, 7(1), 91.

Helfat, C.E., Finkelstein, S., Mitchell, W., Peteraf, M.A, Singh, H. \& Winter, S.G. (2007). Dynamic Capabilities: Understanding strategic change in organizations. Malden, MA: Blackwell Publishing.

Hjalager, A. M. (2010). A review of innovation research in tourism. Tourism management, 31(1), 1-12.

Hofer, C. W. \& Schendel, D. E. (1978). Strategy formulation: analysis and concepts. St. Paul, MN: West Publishing.

Hung, R. Y. Y., Yang, B., Lien, B. Y. H., McLean, G. N. \& Kuo, Y. M. (2010). Dynamic capability: Impact of process alignment and organizational learning culture on performance. Journal of World Business, 45(3), 285294.

Jovchelovitch, S. \& Bauer, M.W. (2000). Narrative interviewing. In M.W. Bauer \& G. Gaskell (Eds.), Qualitative Researching with Text, Image and Sound (pp. 57-74). London: Sage.

Lee, P. Y., Lin, H. T., Chen, H. H. \& Shyr, Y. H. (2011). Dynamic capabilities exploitation of market and hierarchy governance structures: an empirical comparison of Taiwan and South Korea. Journal of World Business, 46(3), 359-370.

Liao, J. J., Kickul, J. R. \& Ma, H. (2009). Organizational dynamic capability and innovation: An empirical examination of internet firms. Journal of Small Business Management, 47(3), 263-286.

Makadok, R. (2001). Toward a synthesis of the resource-based and dynamiccapability views of rent. Strategic Management Journal, 22, 387-401.

Nieves, J. \& Haller, S. (2014). Building dynamic capabilities through knowledge resources. Tourism Management, 40, 224-232.

Patton, M. Q. (1990). Qualitative evaluation and research methods (2nd ed.). Newbury Park, CA: Sage Publications, Inc. 
Penrose, E.T. (1959). The theory of the growth of the firm. Oxford: Basil Blackwell.

Peters, M., \& Pikkemaat, B. (2006). Innovation in tourism. Journal of Quality Assurance in Hospitality \& Tourism, 6(3-4), 1-6.

Porter, M.E. (1980). Competitive strategy. New York: Free Press.

Porter, M.E. (1985). Technology and competitive advantage. Journal of Business Strategy, 5(3), 60-78.

Prieto, I. M., Revilla, E. \& Rodríguez-Prado, B. (2009). Building dynamic capabilities in product development: how do contextual antecedents matter? Scandinavian Journal of Management, 25(3), 313-326.

Sapienza, H. J., Autio, E., George, G. \& Zahra, S. A. (2006). A Capabilities perspective on the effects of early internationalization on firm survival and growth. Academy of Management Review, 31(4), 914-933.

Sarasvathy, S. (2001). Causation and effectuation: toward a theoretical shift from economic inevitability to entrepreneurial contingency. Academy of Management, 26(2), 243-263.

Saunders, M., Lewis, P. \& Thornhill, A. (2009). Research methods for business students. Harlow: FT/Prentice Hall.

Schumpeter, J.A. (1934). The theory of economic development. Cambridge. MA: Harvard University Press.

Sher, P. J. \& Lee, V. C. (2004). Information technology as a facilitator for enhancing dynamic capabilities through knowledge management. Information \& Management, 41(8), 933-945.

Stenholm, P. \& Toivonen, J. (2009), The attributes of firm growth - why and why not a firm does grow". Frontiers of Entrepreneurship Research, 29, $1-15$.

Stinchcombe, A.L. (1965). Organizations and social structure. In J. G. March (Ed.), Handbook of organizations (pp. 142-193). Chicago: Rand McNally.

Teece D.J., Pisano, G. \& Shuen, A. (1997). Dynamic capabilities and strategic management. Strategic Management Journal, 18(7), 509-533.

Teece, D.J. (2000). Strategies for managing knowledge assets: the role of firm structure and industrial context. Long Range Planning, 33(1), 35-54.

Teece, D.J. (2007). Explicating dynamic capabilities: the nature and microfoundations of (sustainable) enterprise performance. Strategic Management Journal, 28, 1319-1350.

Teece, D.J. (2012). Dynamic capabilities: routines versus entrepreneurial action. Journal of Management Studies, 49, 1395-1401.

Teece, D.J. (2014). A dynamic capabilities-based entrepreneurial theory of the multinational enterprise. Journal of International Business Studies, 45(1), 8-37.

Weiermair, K. \& Peters, M. (2002). Innovation and innovation behaviour in hospitality and tourism: problems and prospects. In Tourism in Asia: development, marketing and sustainability (pp. 600-612). Fifth Biennial Conference, Conference proceedings, Hong Kong, China. 
Winter, S.G. (2003). Understanding dynamic capabilities. Strategic Management Journal, 24 (10), 991-995Wu, L. Y. (2007). Entrepreneurial resources, dynamic capabilities and start-up performance of Taiwan's high-tech firms. Journal of Business Research, 60(5), 549-555.

Yin, R. K. (1989). Case study research: design and methods. Revised edition. Applied Social Research Methods Series, 5.

Zahra, S., Sapienza, A. \& Davidsson, P. (2006). Entrepreneurship and Dynamic Capabilities: A Review, Model and Research Agenda. Journal of Management Studies, 43(4), 917-955.

Zheng, S., Zhang, W. \& Du, J. (2011). Knowledge-based dynamic capabilities and innovation in networked environments. Journal of Knowledge Management, 15(6), 1035-1051.

Zhou, K. Z. \& Li, C. B. (2010). How strategic orientations influence the building of dynamic capability in emerging economies. Journal of Business Research, 63(3), 224-231.

Zollo M. \& S. G. Winter (2002). Deliberate learning and the evolution of dynamic capabilities. Organization Science, 13, 339-351.

Zott, C. (2003). Dynamic capabilities and the emergence of intra-industry differential firm performance: insights from a simulation study. Strategic Management Journal, 24(2), 97-125.

\section{Abstrakt (in Polish)}

Jakkolwiek rezultaty badań sugerujq, że rozwój dynamicznych zdolności (DZ) stanowi kluczowy czynnik osiqgania i zachowania przewagi konkurencyjnej dla wzrostu, nie zbadano w pełni w jaki sposób mate i średnie przedsiębiorstwa (MSP) tworzq, identyfikujq i wykorzystujq szanse na ekspansję, szczególnie w krajach rozwijajqcych się i o ograniczonych zasobach. Celem badania jest określenie, w jaki sposób MSP budujq zdolności do wzrostu w specyficznym kontekście krajów rozwijajqcych się i w warunkach ograniczonych zasobów. Dla szczegółowego opisu tych procesów zastosowano jakościowq metodykę, opartq na porównawczej analizie opisów przypadku ośmiu MSP, w sektorach oprogramowania i turystyki w Argentynie. Sektory te były uprzednio określone jako sektory dynamiczne i o wysokim potencjale wzrostu. Wyniki sugerujq, że MSP rozwijaja DZ głównie poprzez wyłaniajqcy się proces powtarzalnych eksperymentów, nie zaś poprzez planowanie strategiczne. Proces ten polega na koordynacji organizacyjnych działań i zasobów, w której to koordynacji menedżerowie odgrywajq kluczowq rolę.

Słowa kluczowe: wzrost firmy, dynamiczne zdolności, MSP, kraje rozwijajqce się. 


\section{Biographical notes}

Claudia D`Annunzio is Director and Researcher of highest category in the national research system Argentina at the Center for Studies in Administration (CEA) on issues related to entrepreneurship, business development, and local development. Master in Business Administration (National University of Central of Buenos Aires Province) and full Professor of Organization Theory and Entrepreneurship Program. She is member of the Scientific Advisory Board of the UNCPBA and committees at national level. She is also a Board Member of the Civil Association Network MERCOSUR SMEs.

Mariela Carattoli is Master in Economics and Industrial Development with a major in SMEs (National University of General Sarmiento), Master in Business Administration and Bachelor of Administration (National University of Central of Buenos Aires Province) and is currently completing her Ph.D.. She is a lecturer in the area of organization theory and researcher at the Center for Studies in Administration (CEA) on issues related to networks, capacity building and business growth.

Dolores Dupleix got her Accountancy degree and now is an MBA and doctoral student at the National University of the Center of Buenos Aires Province in Argentina. She got a five-year scholarship from the CONICET. Dolores Dupleix is a researcher and teaching assistant at the Center of Administration Studies in that same institution. Her current research interests focus on entrepreneurship, SMEs, and firm growth. 